\title{
Challenges for Adopting Inflation Targeting Regime in Egypt
}

\author{
Ibrahim L. Awad \\ Teacher of Economics- Department of Economics- \\ Faculty of Commerce- Zagazig University \\ e-mail: ibrahimphd@yahoo.com
}




\section{ملخص}

تستهدف هذه الدر اسة بحث التحديات التى تواجه البنك المركزى المصرى عند تطبيقة لنظام

استهداف التضخم. فمن خلال الاستفادة من خبرة جمهورية التشيك و بولندا و البرازيل فى المر احل الأولى لاختيار هم نظام استهداف التضخم ابرزت الدراسة التحديات التالية التى تواجه البنك المركزى المصرى: (أ) على البنك المركزى المصرى ان يلعب دورا نشطا لاقناع دوائر صنع القرار داخل الحكومة بتبنى نظام استهداف التضخم. (ب) يجب ان يكون البنك المركزى المصرى مستقلا بشكل حقيقى. (ج) يجب توطيد التعاون بين السياسة النقدية و السياسة المالية بحيث يكون الهدف المطلوب تحقيقة فيما يخص معدل التضخم محددا بالثكل الذى يضمن قدرة الحكومة على الوفاء بالتز اماتها. (د) يجب ان يكون البنلك المركزى على در اية واسعة فيما يتعلق بعدد من القضايا هى ، درجة اثر اختراق سعر الصرف، مستوى سعر الصرف الحقيقى، ناثير و توقيت آليات السياسة النقدية. (هـ) لا يز ال هناك عددا من الأسئلة الملحة: اى مقياس للأسعار سيتم استهدافة؟ ما هى المتغيرات التى سيتم تضمينها فى دالة هدف البنك المركزى المصرى؟ و ما هى الأوزان النسبية التى سيتم اعطاءها لهذه المتغير ات؟ ما هو النموذج الذى يناسب الاقتصاد المصرى؟ كيف يمكن ان يكون رد فعل البنك المركزى المصرى لصدمات العرض و الفقاعات فى اسعار الأصول؟ ما هو المستوى التوازنى لكل من سعر الصرف الحقبقى و اسعار العقار ات؟ و كيف يمكن للبنك . المركزى المصرى ان يكتشف انحر اف كل من سعر الصرف الحقيقى الفعلى و الأسعار الفعلية للعقار ات عن مستوى السعر التوازنى لكل منهما بشكل آنى؟ هل اعضاء لجنة السياسة النقدية مؤهلين بشكل كافى لتقييم مخاطر التنبؤ و مخاطر القرارات المترتبطة به؟ (و) بعض الترتيبات المؤسسية المطلوب تنفيذها بشكل ضرورى تشمل استقصاء القطاع العائلى بشان التوقعات التضخمية و تطوير و تحديث البيانات الاحصائية بالثكل الذى يستوفى المعايير الدولية و خصوصا تلك المستخدمة بو اسطة صندوق النقد الدولى طبقا لاطار تقييم جودة البيانات. 


\section{Abstract}

This study intends to investigate challenges facing the CBE for adopting IT regime. Through exploiting the experience of Czech Republic, Poland, and Brazil in their early days of adopting IT the study highlights the following challenges that are facing the CBE; (i) A more active role to be played by the CBE is needed to convince decision-making circuits inside the government for the adoption of IT. (ii) The CBE should be factually independent. (iii) Coordination between monetary policy and fiscal policy should be established so that the inflation target given to the CBE is determined to ensure the government's solvency. (iv) A satisfactory level of knowledge has to be acquired by the CBE concerning the following issues; the degree of the exchange rate pass-through effect, the level of real exchange rate, and both timing and effect of monetary transmission mechanisms. (v) Several questions are still unfulfilled; Which measurement of price level that will be targeted? What are variables that will be included in the objective function of the CBE? And what are relative weights that will be assigned to these variables? What is the model that fits the Egyptian economy? How would the CBE react to both supply shocks and asset-price bubbles? What is the equilibrium level of both real FX rate and property prices? How can the CBE detect deviations of both the actual real FX rate and actual property prices from their equilibrium levels in real time? Are the MPC members qualified enough to give adequate assessment of the risks of the forecasts and the associated decisions? (vi) Some institutional arrangements are urgently needed both to implement a household survey of inflation expectations and to improve and update the Egyptian statistics in order to meet the international criteria, especially that used by the IMF under the DQAF.

Keywords: Monetary policy; Inflation targeting regime; Adopting inflation targeting in Egypt;

JEL: E31, E58, E61 


\section{Introduction}

Beginning in the 90s decade, and after the first adoption of inflation targeting (IT) by New Zealand, an increasing number of developed and emerging market economies have adopted IT. IT was almost adopted by industrial countries through the 1990s. In addition, increasing numbers of emerging market economies have adopted IT since the late 1990s, and these countries are now representing the substantial majority of inflation targeters. In a survey by the IMF staff (Batini, et al., 2006, PP. 7-8), more than half of the 88 non-industrial countries expressed a desire to move to explicit or implicit quantitative inflation targets in 2010. According to Roger $(2009,6)$, twenty-nine countries are classified as inflation targeters as of mid-2009, including fourteen high-income countries and fifteen lowincome countries. In addition, European Central Bank, the Swiss National Bank, and the Federal Reserve Bank have moved toward regimes that have many attributes of IT.

IT has been introduced under the assumption that the main goal of monetary policy is to achieve price stability, i.e. low and stable rate of inflation ${ }^{1}$. Such an assumption is widely accepted today. Masson, et al. $(1998,34)$ and Truman, $(2003,5)$ indicated that the reason that this assumption became widely accepted may refer to the general agreement on

\footnotetext{
${ }^{1}$ A strict definition of price stability suggests an inflation rate at or very near zero. Although the change in the CPI is widely used to measure the inflation rate, the CPI may involve a downward bias. This is why some economists indicate that targeting the inflation rate at zero level may create serious problems. These problems refer to the fact that both inflation and deflation have a negative impact on the economic activity. IT from this perspective is designed for achieving price stability (fighting both inflation and deflation) through hitting a target of inflation (Bernanke et al., 1999, 28-30).
} 
the following four propositions ${ }^{2}$ : (i) Money supply is neutral in the long run. That is, in the long run money supply does not affect real variables, i.e. an increase in money supply leads only to a higher price level without affecting real variables, e.g. output and employment. A stronger version of this proposition is that money supply has no or limited effect on the real variables in the medium run. (ii) Money supply is not neutral in the short run. That is, monetary policy has transitory effects on the real variables in the short run. (iii) Monetary policy lags are long and variable. Consequently, the Central Bank (CB) will find it difficult, if not impossible, to conduct monetary policy upon a period-by-period basis, and (iv) High and variable (volatile) inflation is costly in terms of the long run growth of real output.

The outbreak of the $25^{\text {th }}$ January Revolution in Egypt in 2011 and the security instability followed it casted dark shadows on tourism, travel, and national investment, which drove down employment and production rates. As a result, real GDP growth at constant prices receded to 1.8 percent in 2010/2011 compared with 5.1 percent in the previous fiscal year. The decline in GDP growth intensified in Q3 (Jan./March 2011), where GDP at constant prices recorded to a negative 4.2 percent (against a positive 5.4 percent) due to the spillovers of the Revolution. The decline in the real growth was accompanied by an increase in the headline CPI inflation from 10.1 percent in June 2010 to 11.8 percent in June 2011. Moreover, during the fiscal year 2010/2011 the value of the Egyptian pound declined by 4.6 percent. As explained by The Central Bank of Egypt (CBE), the decline in

\footnotetext{
2 These propositions reflect the assumptions of Friedman's model of inflation. For more discussions about money market and monetarists see; Carlin and Soskice (1990) and Blanchard \&Fisher (1993).
} 
the current account balance including tourism receipts, and negative values recorded by FDI, resulted in a plummet in the net international reserves of the CBE from US\$ 36 billion at the end of December 2010 to US\$ 18 billion at the end of December $2011^{3}$.

The reaction of $\mathrm{CBE}$ to these dramatic developments in inflation and real GDP growth (CBE, Annual report 2010/2011) is that; "monetary policy continued to be supportive of economic growth, and in line with the overriding objective of the monetary policy (price stability). The monetary policy committee (MPC)'s decisions were tuned to this objective, keeping the overnight deposit and lending rates broadly unchanged at 8.25 percent and 9.75 percent, respectively, and the discount rate at 8.5 percent" ${ }^{4}$.

Indeed, Egypt, according to the IMF survey (Batini, et al., 2006, PP. 78), is counted as one of the prospective candidates to adopt IT in the near future. The CBE announced on several occasions its intention to adopt IT once the fundamental prerequisites are met (IMF, 2007 and CBE, 2005). Moreover, the CBE (2007) stated that they are applying implicit inflation targets, which will be announced once the CBE completes building up its inflation-targeting framework in coordination with the $\mathrm{IMF}^{5}$. To date, the CBE did not announce a precise inflation target, and did not disclose

\footnotetext{
3 For more details on the developments of other macroeconomic variables followed the 25th revolution, see; CBE, Annual report 2010/2011.

4 In March 2011, the MPC practiced repos to pump funds into the banking system. In November 2011, the MPC raised the overnight deposit rate by 100 basis points, the overnight lending rate by 50 basis points, and the discount rate by 100 basis points. Thus the deposit rate raised to 9.25 percent, the lending rate raised to 10.25 percent, and the discount rate raised to 9.5 percent.

5 This statement by the CBE was in the context of its response to the critique of Morgan Stanley report, published on March 28, 2007, about the overriding of the government, specifically the prime minister, on the decision making process inside the CBE. Recently, the CBE mentioned that it is currently doing in the transitional period until a full-fledged IT (see FAQ, available on; http://www.cbe.org.eg/Monetary-Policy/FrameWork.htm
} 
information about prerequisites of IT that have been achieved and that which are still unfulfilled.

This paper set out to explore prerequisites of IT that have been accomplished by the CBE, and that which are still unfulfilled. The paper exploits the experience of some emerging market economies, i.e. Czech Republic, Poland, and Brazil (CPB), to draw lessons that might be helpful for the case of Egypt. Thus, the study considers the availability of prerequisites of IT in Egypt compared with CPB in the early days of their adopting IT. Given political intention to adopt IT, the study presumes that a country will apply IT once prerequisites of IT have been satisfied.

This paper is organized as follows: Section 2 explores definition, model, and motives to the IT. Section 3 discusses prerequisites for a successful full-fledged IT. Section 4 underscores limits of IT. Section 5 considers the experience of CPB. Section 6 draws lessons from the experience of CPB. Section 7 considers the availability of prerequisites of IT in Egypt compared with CPB. Section 8 concludes.

\section{IT: definition, model, and motives}

\subsection{Definition of IT}

Generally speaking, there is no standard definition of $\mathrm{IT}^{6}$. However, we can think of IT as a way of reforming monetary policy through

\footnotetext{
${ }^{6}$ The definitions of IT in the literature differ; see, for example, Debelle et al. (1998, p. 2), Svensson (1998, p. 13), Batini et al. (2005, p. 161), Bernanke and Woodford (2005, p. 1) and King (2005, p. 13). The disagreement among economists is not only about an exact definition of IT but also about classifying some countries into inflation targeters and non-inflation targeters during transitional periods. In practice, some countries began with "partial" IT rather than "fullfledged" IT, e.g. Chile, Colombia, Israel, Peru and Mexico. Consequently, classifying such countries as inflation targeters or non-inflation targeters during a transitional period is likely to=
} 
anchoring individuals' expectations about inflation around an announced target of inflation.

In a flexible IT regime, the short-term interest rate serves as the operational target of monetary policy. The connection between the operational target and the ultimate target(s) is the inflation forecast, which serves as the intermediate target of monetary policy. For this reason, the inflation forecast plays a pivotal role in the targeting process.

IT as a constrained discretion is a way of implementing the optimal policy reaction function ${ }^{7}$. The $\mathrm{CB}$ or the government determines the targeted level/range of inflation. On the basis of the forecasted level of inflation, the $\mathrm{CB}$ moves the short-term interest rate to drive the expected, and consequently the actual rate of inflation towards the targeted level.

The targeted level of inflation should be publicly announced to serve as an "anchor" for individuals' expectations about the future path of inflation. The announced inflation target is expected to play the role of anchoring individuals' expectations as long as the CB's credibility is high. This is why CB credibility represents a cornerstone for a successful IT. Accountability, transparency and independency are the three basic pillars for CB's credibility.

\subsection{The model of IT}

2.2.1 A simple macroeconomic framework: The framework that underpins the modern monetary policy models is grounded in dynamic

=involve subjective choices. See: Truman (2003, 6), Masson et al. (1998, 35), Schmidt-Hebbel and Tapia (2002), and Mishkin and Schmidt-Hebbel (2001).

${ }^{7}$ Indeed, most economists regard IT as a constrained discretion. The constraint is the inflation target and the discretion is the scope to take account of short-run economic and financial considerations. For more details, see Truman (2003) and Bernanke and Mishkin (1997). 
general equilibrium theory. The model combines the assumption of dynamic optimizing behavior by private agents with temporary nominal rigidities. Within the model, monetary policy affects the real economy in the short-run, much as the traditional LM/IS framework but the behavioral equations of the model evolve from optimization by private agents.

The model is widely known in the literature and incorporates two equations as follows [Clarida, Gali, and Gertler (1999), Woodford (2003), Svensson (1995), Svensson and Woodford (2005), and Walsh (2009)];

$$
\begin{aligned}
& x_{t}=-\phi\left[i_{t}-E_{t} \pi_{t+1}\right]+E_{t} x_{t+1}+g_{t} \\
& \left(\pi_{t}-\pi^{T}\right)=\lambda x_{t}+\beta E_{t}\left(\pi_{t+1}-\pi^{T}\right)+\mu_{t}
\end{aligned}
$$

Where $x_{t}$ represents the output gap defined as the difference between actual output $\left(y_{t}\right)$ and potential output $\left(z_{t}\right)$, i.e. $x_{t} \equiv\left(y_{t}-z_{t}\right), i_{t}$ represents the policy interest rate, $\pi_{\mathrm{t}}$ is the inflation rate, and $\pi^{\mathrm{T}}$ is the central bank's inflation target. $\mathrm{g}_{\mathrm{t}}$ and $\mu_{\mathrm{t}}$ are disturbance terms follow autoregressive process like 3 and 4.

$$
\begin{aligned}
& g_{t}=\alpha g_{t-1}+e_{t} \\
& \mu_{t}=\rho \mu_{t-1}+s_{t}
\end{aligned}
$$

Where $0 \leq \alpha, \rho \leq 1$ and both $\mathrm{e}_{\mathrm{t}}$ and $\varsigma_{\mathrm{t}}$ are i.i.d random variables with zero mean and constant variance.

Equation 1 represents the expectational IS curve which is derived from the Euler conditions for optimal consumption ${ }^{8}$. It relates the output gap

\footnotetext{
${ }^{8}$ For details on the derivation of the equations 1 and 2 see; Clarida, Gali, and Gertler (1999).
} 
inversely to the real interest rate. It also differs from the traditional IS curve because current output gap depends on the expected output gap and nominal interest rate. Higher expected future output raises current output gap where people consume more today because of expectation of higher output, hence income, in the future. The negative effect of real interest rate on current output gap reflects intertemporal substitution of consumption. The mechanism of monetary policy mirrored by the expectational IS curve is simple. By moving policy rate, $i_{t}, C B$ changes real interest rate because price adjusts sluggishly. By altering the real interest rate aggregate spending, hence $x_{t}$ is affected. How much percentage change in $x_{t}$ because of change in real interest rate, it depends on the intertemporal elasticity of substitution, $\phi$. The disturbance $g_{t}$ can arise due to shocks to aggregate productivity, consumer preferences, risk aversion, or fluctuation in fiscal policy.

Equation 2 represents the new Keynesian Phillips curve. It depicts AS relationship which is grounded in the individual price-setting decision and derived from an explicit optimization problem.

The above model, however, does not take into account the effect of exchange rate shocks and shocks from the rest of the world on domestic inflation. In an open economy, the movements of real exchange rate, the relative price between domestic and foreign goods, will affect both domestic and foreign demand for domestic goods. In addition, the movements in nominal exchange rate will affect domestic prices of both intermediate and final goods imported from foreign countries which in turn will induce movements in the nominal wages thereby the cost of 
domestically produced goods will be affected. Moreover, some foreign disturbances will be transmitted into domestic economy through the exchange rate channel, e.g., changes in foreign prices, and foreign interest rates.

A forward-looking model which incorporates aspects of open economy is used by Batini and Haldan (1999), and Batini and Nelson (2000). The structural equations of this model are as follow ${ }^{9}$;

$$
\begin{aligned}
& \mathrm{y}_{\mathrm{t}}=\mathrm{E}_{\mathrm{t}} \mathrm{y}_{\mathrm{t}+1}-\sigma\left(\mathrm{i}_{\mathrm{t}}-\mathrm{E}_{\mathrm{t}} \pi_{\mathrm{t}+1}\right)+\eta \tilde{\mathrm{A}}_{\mathrm{t}}+\mathrm{e}_{\mathrm{y}} \\
& \pi_{\mathrm{t}}=\alpha \pi_{\mathrm{t}+1}+(1-\alpha) \mathrm{E}_{\mathrm{t}} \pi_{\mathrm{t}+1}+\theta_{\mathrm{y}} \mathrm{y}_{\mathrm{t}-1}+\theta_{\tilde{\mathrm{A}}} \tilde{\mathrm{A}}_{\mathrm{t}-1}+\mathrm{e}_{\pi} \\
& \mathrm{E}_{\mathrm{t}} \mathrm{A}_{\mathrm{t}+1}=\mathrm{A}_{\mathrm{t}}+\mathrm{i}_{\mathrm{t}}-\mathrm{E}_{\mathrm{t}} \pi_{\mathrm{t}+1}++\mathrm{K}_{\mathrm{t}}
\end{aligned}
$$

Where, equation 5 is the IS relationship which corresponds to the optimization-based IS function in McCallum and Nelson (1999). Equation 6 is the open-economy's Phillips curve which corresponds to Ball (1999). Equation 7 represents the uncovered interest rate parity. Variables $y_{t}, \pi_{t}, i_{t}$, and $A_{t}$ are real output, inflation, nominal interest rate, and real exchange rate (measured so that a rise is a depreciation), respectively. $\tilde{\mathrm{A}}_{\mathrm{t}}(=0.25$ $\left.\sum_{j=1}^{4} A_{t}\right)$ is a four-quarter moving average of $A_{t}$. The variables are all expressed relative to steady-state values. $\mathrm{e}_{\mathrm{y}}, \mathrm{e}_{\pi}$, and $\mathrm{K}_{\mathrm{t}}$ are exogenous shocks in IS curve, Phillips curve, and uncovered interest rate parity, respectively.

The way the foreign exchange rate enters both IS and Phillips curve relationships depends on the specification of the model of the economy

\footnotetext{
${ }^{9}$ A similar form of this model was used by Svensson (1998), and Bharuch and Kent (1998).
} 
under consideration. If the impact of pass-through of foreign exchange rate to exports and imports prices is gradual and prolonged, a backward-looking of foreign exchange rate is appropriated. If not, exchange rate might be introduced in a forward-looking manner by putting $A_{t}$ and $E_{t} A_{t+1}$ in the IS curve and $\Delta A_{t}$ and $E_{t} \Delta A_{t+1}$ in the Phillips curve (Batini and Nelson, 2000).

Under the above structural equations, a positive shock in the uncovered interest parity, depreciates domestic currency, and affects domestic inflation with lags. In other words, the response of inflation to a depreciation of domestic currency is protracted, as inflation depends on lags of the exchange rate both via the output gap channel and via the direct exchange rate channel.

2.2.2 The policy objective and monetary policy reaction function: The mandates for the most CBs usually oblige the $\mathrm{CB}$ to achieve the inflation target each year ${ }^{10}$. Because of lags of monetary policy transmission to inflation, $C B$ focuses on the expected inflation to fulfill its mandate ${ }^{11}$. That requires that the $\mathrm{CB}$ has to estimate monetary transmission and quantify the existing lags to take the decision in advance upon the forecasted inflation in

\footnotetext{
10 For instance, as we will see later, the mandate for CBs in the Czech Republic, Poland, and Brazil consider the inflation target is fulfilled when inflation, measured by year-on-year increase in the CPI, lies inside the tolerance intervals, or very close to the target level. Also, according to the European central bank, price stability is defined as year-on-year increase in the harmonized index of consumer price index for Euro area of below 2\% (ECB, 1999).

${ }^{11}$ For example, Awad (2011) estimated monetary transmission mechanisms in Egypt during the periods 1998-2002 and 2004-2009. Despite the impact of monetary expansion on both real GDP gap and domestic price did not incorporate substantial change during the two periods, the impact of monetary policy actions on domestic prices became faster and higher in the last period where a positive shock in the short-term interest rate significantly decreases domestic price after one lag ( three months).
} 
such a way that would guarantee hitting the target of inflation (Batini and Nelson, 2000).

In the literature, the forward-looking approach on the IT is represented by two ways; (i) A targeting rule, where the $\mathrm{CB}$ uses all available and relevant information to bring the target variable in line with the target level. In doing so, the $\mathrm{CB}$ minimizes the loss function over expected future deviation of the target variable from the target level of this variable. Targeting inflation under this meaning is advocated by Rudebusch and Svensson (1999), and Svensson (1997, \& 1995).

Under this meaning, the loss function to be minimized by the $\mathrm{CB}$ is a quadratic function and incorporates the following variables;

$$
\begin{aligned}
& \text { Mini } E_{t} \sum_{j=0}^{\infty} \alpha^{j} L_{t+j} \\
& L_{t}=\lambda_{\pi}\left(\pi_{t+j}-\pi_{t+j}^{T}\right)^{2}+\lambda_{\pi}\left(y_{t+j}-y_{t+j}^{T}\right)^{2}+\lambda_{\Delta i}\left(\Delta i_{t+j}\right)^{212}
\end{aligned}
$$

Where, $\alpha$ is the discount factor. $\pi_{\mathrm{t}}^{\mathrm{T}} \pi_{t}^{T}$, and $\mathrm{y}_{\mathrm{t}}^{\mathrm{T}}$, are the targets of goal variables $\pi_{\mathrm{t}}$, and $\mathrm{y}_{\mathrm{t}}$, respectively. $\left(\Delta \mathrm{i}_{\mathrm{t}+\mathrm{j}}\right)^{2}$ is the volatility of nominal interest rate. $\lambda_{\pi}, \lambda_{\mathrm{y}}$, and $\lambda_{\Delta \mathrm{i}}$ are relative weights assigned to inflation deviation from the target, output deviation from potential output, and volatility of nominal interest rate. Svensson (1997) makes difference between strict and flexible inflation targeting. Strict inflation targeting refers to the situation where only inflation enters the loss function $\left(\lambda_{\mathrm{y}}=\Delta \mathrm{i}_{\mathrm{t}}\right.$

\footnotetext{
${ }^{12}$ The objective function, or loss function, is mostly expressed as a function of both inflation deviations from the target and output deviations from 'natural' or 'equilibrium' or 'potential' output. Moreover, output deviations can be substituted by deviations of actual unemployment from NAIRU. For more details, see; Blinder, A. S. (2006).
} 
$=0$ ), whereas flexible inflation targeting allows other variables by assigning some weights to $\lambda_{\mathrm{y}}$ and $\Delta \mathrm{i}_{\mathrm{t}}$.

By assuming that the objective of monetary policy is to minimize the squared deviations of output and inflation from their respective target levels, Clarida, Gali, and Gertler (1999) used a similar form to (9) which is formally a quadratic a approximation of the utility-based function provided by Rotemberg, J. and Woodford, M. (1999), and Woodford (1998), such that;

$$
L_{t}=\pi_{t+j}^{2}+\lambda_{y}\left(y_{t+j}-y_{t+j}^{T}\right)^{2}
$$

Where inflation target is supposed to be zero $\left(\pi_{t}^{T}=0\right)$, and there is no cost in terms of generality since inflation is expressed as a percent deviation from the trend.

Under the above structure, the policy problem is to choose a time path for the instrument $i_{t}$ to engineer time paths of the target variables that minimize the objective function (8), subject to the constraints (1) and (2) or (5-7). Under a loss function like (10), a discretionary monetary policy determines the triplet, $\pi_{t}, y_{t}$ and $i_{t}$ through two stages. Firstly, the CB chooses $\pi_{t}$, and $y_{t}$ that maximize the objective function, given the Phillips curve equation. Secondly, conditional on the optimal valued of $\pi_{t}$, and $y_{t}$ the CB determines the value of the instrument $i_{t}$ implied by the IS curve equation, i.e. the interest rate that will support $\pi_{t}$, and $y_{t}$ (Clarida, Gali, and Gertler, 1999, P.1671). 
(ii) An instrument rule, where the monetary policy instrument is expressed as an explicit function of available information. Specifically, monetary policy responds to the gap between the target variable and the target level of this variable. Thus the reaction of monetary policy uses a rule such as:

$$
i_{t}=\text { constant }+\lambda_{\pi}\left(E_{t} \pi_{t+j}-\pi_{t}^{T}\right)
$$

Where $E_{t} \pi_{t+j}$ is the period $(t)$ forecast of inflation in $(t+j), \pi_{t}^{T}$ is the inflation target, and $\lambda_{\pi}<1$.

Implementing IT under this meaning is advocated by Batini and Haldane (1999), McCallum and Nelson (1999), and Batini and Nelson (2000). The proponents to this approach think that CB can use (11) to control inflation even if there is no consensus on the appropriate objective function or a model of the economy. All CB may need to implement IT under this approach is to construct inflation forecasts. However, the major weakness of this approach is that it based on a simple rule that uses information less efficiently than the aforementioned optimal rule.

\subsection{Motives to IT}

The spread of IT in different countries led to the question, 'Why have many countries decided to switch their monetary policy regimes to the IT? In most countries, the shift toward adopting IT was because of unsatisfactory economic performance under other monetary policy regimes. In some other cases the adopting of IT was a part of a comprehensive economic reform, e.g. the case of Central and Eastern Europe. In general, 
two factors lie behind adopting IT; IT is a way of reforming monetary policy, and IT does not worsen economic performance ${ }^{13}$.

2.3.1 IT is a way of reforming monetary policy: It is widely accepted today that a monetary policy regime is efficient as long as it is able to achieve the goal of price stability ${ }^{14}$. In this respect, a nominal monetary policy anchor is necessary for price stability, because it ties down individuals' expectations about the price level ${ }^{15}$. Thus, the efficiency of a monetary policy regime is determined, first of all, by the ability of the embedded nominal anchor to send the right message to all the practitioners about the potential behavior of the price level. In this context, IT is a way of reforming monetary policy through anchoring individuals' expectations about inflation around an announced inflation target.

As we will see later, countries such as the Czech Republic, Poland and Brazil were forced to float their currencies in the aftermath of economic crises in order not to lose a large part of their foreign reserves. The decision to float came in the wake of speculative attacks on the domestic currency triggered by both economic crises and external imbalances on their current accounts. These current account imbalances emerged because of pegging of the exchange rate in conjunction with high domestic inflation, with real appreciation thus occurring. Immediately after floating domestic currency,

\footnotetext{
${ }^{13}$ Of course, there are other factors for the rapid spread of IT, but they are related to the two factors mentioned in the text. Epstein, G. (2007), for instance, thinks that the spread of IT is due to the IMF increasingly using loan conditions and technical assistance to promote the use of IT in developing countries and emerging market economies.

${ }^{14}$ An operational definition of price stability that is now broadly accepted among economists is the one presented by Alan Greenspan: price stability is obtained when economic agents no longer take account of the prospective change in the general price level in their economic decision-making (Batini, N., Kuttner, K., and Laxton, D., 2005, p. 161).

${ }^{15}$ Mishkin (1999, p. 1) defines a nominal anchor as a constraint on the value of money. It provides conditions that make the price level uniquely determined. A nominal anchor for this reason is a device to bind individuals' expectations about the nominal price level.
} 
$\mathrm{CBs}$ in these countries switched their monetary policy regimes to the IT because they found that IT was the only available option for achieving the goal of price stability on a forward-looking basis. On the one hand, a monetary policy regime without an explicit nominal anchor, i.e. 'just do it' policy, was not an appropriate alternative for tying down individuals' expectations about the future path of inflation, especially as the CBs in these countries did not have a track record of credibility during that time. On the other hand, a monetary targeting regime was not also an appropriate alternative, especially after the liberalization of capital flows and financial markets, which undermined the relationship between the money supply and the price level (Schaechter et al. 2000; Jonas and Mishkin, 2003; Fraga, 2000; Arestis et al., 2008).

2.3.2 IT does not worsen economic performance: There is no agreement among economists in the literature about the contribution of IT to economic performance. For example, Truman (2003, p. 33) attributes the spread of IT especially during the 1990s to the suitable global macroeconomic environment during this period, which gave a good name and a good start to the IT regime.

However, the disagreement among economists about the contribution of IT to economic performance may be due to the conflicting results of empirical studies. On the one hand, Mishkin and Schmidt-Hebbel (2001) found that IT is beneficial especially with regards to reducing the rate of inflation, reducing the sacrifice ratio and output volatility, guiding inflation expectations and dealing better with inflation shocks, reinforcing central bank independence and mutually reinforcing communications, transparency, and accountability. Neumann and Hagen (2002) found 
similar results regarding the volatility of inflation and output. In addition, Landerretche et al. (2001) found similar results about the output sacrifice, the volatility of industrial output and reducing inflation forecast errors based on country VAR models.

On the other hand, some studies have found that IT does not contribute to economic performance. Bernanke et al. (1999) show that the adoption of IT did not make a difference with regards to the cost and speed of price stabilization. Cecchetti and Ehrmann (1999) found that the degree of inflation aversion and consequently the degree of output volatility in the inflation-targeting countries in average is not higher than those of nontargeters. Comparing 7 inflation targeters to 13 non-targeters, Ball and Niamh (2003) found that the performance improved in both groups after the early 1990s and there was no evidence that IT improved performance.

However, Hu (2003) takes a middle stance based on the results of an empirical study of about 66 countries for the period 1980-2000. The author found limited support for the proposition that the adoption of IT improves the trade-off between inflation and output variability, although IT does play a beneficial role in improving the performance of inflation and output.

Nevertheless, the above dispute about the contribution of IT to economic performance does not mean that IT worsened economic performance. So far, there are no empirical studies supporting the proposition that IT has worsened economic performance.

\section{Prerequisites for a successful IT}

In the literature, there are considerable debates about prerequisites/preconditions that a country has to meet before adopting IT. 
These debates reflect the fact that there is no generally agreed set of preconditions.

Preconditions that are frequently desired by most economists (Khan, 2003, P.10; Truman, 2003, P. 49; Batini, et al. 2006, P. 18 and Jonas and Mishkin, 2003, P. 6) include: (i) A commitment to price stability as a primary goal of monetary policy. (ii) $\mathrm{CB}$ has to have legal independence. (iii) Macroeconomic stability has to exist. (v) Monetary policy has to be transparent and the $\mathrm{CB}$ has to be accountable. (vi) Absence of fiscal dominance. (vii) Institutional elements include; measuring monetary transmission mechanisms, forecasting inflation and coordination between monetary and fiscal policy.

Nevertheless, there is no agreement among economists regarding the question of "what are prerequisites that have to be met before the adoption of IT in the emerging market economies?' Eichengreen, et al. (1999) argue that emerging market economies are severely lacking technical capabilities and central bank autonomy. Consequently, these countries will be better off with a conventional monetary policy framework; e.g. targeting the exchange rate or targeting monetary aggregates. Carare et al. (2002) think that the absence of some of preconditions should not preclude the adoption of IT, especially when policies are being introduced to establish them in the short or medium-term. Truman (2003) thinks of preconditions as a part of "full-fledged" inflation targeting that may follow a transitional period, i.e. it is not condition that a country satisfies all prerequisites during the transitional period of IT. Assessing the role of "preconditions" for adopting IT, Batini, et al. (2006, P. 176) found that no inflation-targeting central bank had all "preconditions" in place prior to the adoption of IT. 
In the light of this, one may ask 'which of preconditions has to be met in advance and which of these can be delayed to be fulfilled in the shortterm'? There is no objective criterion. Jonas and Mishkin $(2003,6)$ think that it is not possible to say whether a country has met these requirements or not, it is more a question of the degree to which these preconditions are met to make inflation targeting feasible. A country may not need to adopt IT if it could satisfy the aforementioned list of preconditions under the other monetary policy regimes. Financial crises and the search for a new nominal anchor for monetary policy led many countries to switch their monetary policy regimes to the IT, e.g. Sweden, United Kingdom, Czech Republic and Brazil.

Three basic elements that are frequently demanded in the vast majority of literature as prerequisites for a successful IT regime are: factual (de facto) independence of the $\mathrm{CB}$, Commitment to price stability as a primary goal of monetary policy and forecasting capabilities. In what follows, I will shed lights on these elements.

\subsection{Factual (de facto) independent of $\mathrm{CB}^{16}$}

$\mathrm{CB}$ independence has to be de facto and not only de jure. Full legal independence of a CB (goal independent and instrument independent) is a controversial point among economists but factual instrument independence of a $\mathrm{CB}$ is an indispensable requirement as a precondition for a successful application of IT. A CB should be free to choose the appropriate tools and change them whenever it is necessary without any pressure from the government. In addition, a CB should have techniques and technicians to

16 Several studies stressed this point. See: Truman (2003, PP. 49-52), Masson, et al. (1998, P. 35), Batini, et al. (2006, P. 18), Debelle, et al. (1998 PP. 11-13), Fraga, et al. (2003, PP. 24-25), and Mishkin and Schmidt-Hebbel (2001, P. 5). 
achieve its objective without substantial outside interference. That is, the government may formulate inflation targets and its tolerance intervals and the $\mathrm{CB}$ becomes responsible for achieving it. In the course of achieving inflation targets, a CB should not seek or take instructions from any other body. Therefore, the existence of government representatives in the monetary policy committee (MPC) as voting members must be prohibited. If not, then $\mathrm{CB}$ independence is not factual.

In addition, a contribution of monetary policy to a macroeconomic stability is conditional with a sound of fiscal position (Truman, 2003, P. 51). With fiscal dominance CB independence is not factual even though the $\mathrm{CB}$ possesses both legal instrument independence and non-existence of the government's representatives in the MPC. The existence of fiscal dominance will make it risky for any country to adopt $\mathrm{IT}^{17}$. The most visible version of fiscal dominance is the formal obligation of $\mathrm{CB}$ to finance budget deficit ${ }^{18}$.

Masson, et al. (1998), Debelle, et al. (1998) and Khan (2003) add another dimension that the shallowness of the capital market is also a common indication of fiscal dominance. Firstly, a weak financial system may prevent the $\mathrm{CB}$ to use the interest rate freely to return inflation

\footnotetext{
${ }^{17}$ Fiscal dominance is the situation in which monetary policy is dominated by the financial needs of the government. The connection between factual independence of the central bank and fiscal dominance is often presented as follows; if government does not have sufficient resources to finance its operations in the economy and requires systematically and significantly amounts of finance to meet its obligations, then a country's fiscal requirements are likely to dominate and determine the central bank's operations. In such case, the $\mathrm{CB}$ will not be able to achieve the target of inflation or keep it inside a determined path (Khan 2003).

${ }^{18}$ In a study about political pressure on CBs in the emerging market economies, Awad (2008) evaluated the de facto independent of $\mathrm{CB}$ in terms of the ability of $\mathrm{CB}$ to keep its target of money supply despite government's pressures for higher credit. He found that the CBE could not keep the target of money supply, and such failure refers to fiscal dominance.
} 
forecasts to the targeted path. This is because a fragile financial system is likely to be unable to afford an increase of nominal interest rates associated with the $\mathrm{CB}$ mopping up the liquidity that has been provided at the previous discount window. Secondly, the financial system is often a byproduct of government schemes to extract revenues using various forms of financial repression (interest rate ceiling, high reserve requirements, selective interest rates, and compulsory placement of public debt). Because of its potential impact on the fiscal position, a CB may resist an increase in the market interest rates to correct deviations of forecasted inflation from the target. A related argument is that if the cost of bailing out a weak banking system has a large fiscal burden, it may lead to fiscal dominance (Truman, 2003, P. 52). However, with reasonably effective monetary policy instruments, e.g. the overnight interest rate and the open market operations, the $\mathrm{CB}$ will be able to follow up its target more efficiently.

To sum up, factual independence of a $\mathrm{CB}$ is based on three basic pillars; (i) Legal instrument independence of CB, (ii) Nonexistence of government representatives in the MPC as voting members, and (iii) Absences of fiscal dominance including no obligation for the CB to finance budget deficit, and domestic financial markets should have enough depth to absorb placements of public debt.

\subsection{A commitment to price stability as a primary goal of monetary policy}

That is, the CB should not target any other variables, e.g. exchange rate. A monetary policy under the commitment to other targets will be confined by those targets and as a result, the monetary authority is more likely to fail in hitting the announced target of inflation. In addition, the 
public will have no assurance that the monetary authorities will give a priority to the inflation targets. Such a situation is likely to deteriorate individuals' expectations about the future path of inflation because of uncertainty about the credibility of the announced inflation target. Nevertheless, the $\mathrm{CB}$ should intervene to prevent undesirable effects coming from changes in other macroeconomic variables on the future path of inflation (Khan, 2003, 10), i.e. the CB should intervene to prevent the second round effects of changes in other macroeconomic variables on the rate of inflation.

A commitment to price stability requires some degree of accountability for the $\mathrm{CB}$ about realizing inflation targets. The lessons from international experience as indicated by Bernanke, et al. (1999, P.38, P.296) delivered two forms of accountability; comparing inflation outcomes with the determined targets or obligating the CB to provide the public with convincing rational for the policy choices that it makes. Given that inflation responds to policy after some lags and inflation targets are rarely hit exactly in the short run, second means become the appropriate alternative of maintaining accountability. Practically, many CBs prefer to be more transparent and credible to the public by announcing the escape clauses, i.e. the exceptions from the obligation to fulfill the inflation target. This explains why accountability of CBs is less formalized in practice and why a transparent monetary policy is so important not only as a device to tie down individuals expectations around an announced inflation target but also as a means for accountability of CBs to the public.

To sum up, a commitment to price stability requires two basic elements; (i) The CB should not target any other variables other than 
inflation rate and (ii) $\mathrm{CB}$ should be transparent to the public about the exemptions of its inflation target. Such a transparency is a practical device to make the $\mathrm{CB}$ accountable to the public for achieving the inflation target.

\subsection{Forecasting capabilities}

Because of the time lag between a change of monetary policy instruments and its effect on the inflation rate, IT has to be pursued in a forward-looking manner. That is, the adjustment of monetary policy instruments has to be established on a systematic assessment of the future path of inflation. Consequently, adopting IT in the form of announcing some targets for inflation to be hit in the future and the way will be used to achieve it requires that some arrangements have to be available in advance. These arrangements include (Debelle, et al., 1998, PP. 3-4): (i) A model for inflation forecasting and inflation projections, (ii) The CB has to have a clear idea about monetary transmission mechanisms, and (iii) An inclusive and updated database on different economic variables has to be in place.

\section{Limitations of IT}

A large group of economists expresses skepticism about the feasibility of IT, especially in developing countries and emerging market economies. These skeptics are because of severe institutional weaknesses that exist in many developing countries, e.g. a low level of democracy, a low level of transparency and no institutional independence. In what follows, I will shed

light on some of the repercussions of these institutional weaknesses that can make IT problematic in these countries. 


\subsection{Low credibility of $\mathrm{CB}$ will undermine the function of IT as a nominal anchor}

The key factor that makes IT able to anchor individuals' inflation expectations is the credibility of the CB. IT, from this perspective, is a promise by the $\mathrm{CB}$ to contain inflation within an announced target. Given the CB's credibility, there is no reason to make individuals expect higher or lower inflation in the future, even though inflation is high or low in reality. Thus, IT is successful as long as individuals will build their expectations about the future inflation upon the announced target of inflation rather than the realized inflation ${ }^{19}$.

Given low credibility of the $\mathrm{CB}$ and a long history of high inflation and macroeconomic instability in most developing countries and emerging market economies, credibility of the CB will be strongly shaken if it could not repeatedly hit the announced target of inflation during a determined time horizon. Individuals in such circumstances are likely to stop using the announced inflation target as an anchor for their inflationary expectations or they may expect that the target of inflation will be adjusted in the future. In this case, IT, which was designed originally to bring inflation down, will eventually give way to greater tolerance of higher inflation in the future.

\subsection{Fragile fiscal policy will undermine the monetary policy objectives}

A considerable group of economists is now fully convinced with the idea that the consequences of the interaction between monetary and fiscal

\footnotetext{
${ }^{19}$ As a consequence, the linkage between realized and expected inflation should be weak at the very high and the very low levels of inflation, where the $\mathrm{CB}$ is assumed to intervene to prevent such deviations from the announced target. Using this approach, Korenok and Radchenko (2006) examined the relationship between realized and expected inflation in Australia, Canada, New Zealand, Sweden, and the United Kingdom. They found weak support for expectations anchoring.
} 
policy can exert greater effects on the successfulness of IT. Fanizza and Sderling (2006) argue that the fiscal theory of price level could explain developments in the price level in countries like Algeria, Egypt, Lebanon, Morocco and Tunisia. They emphasized the importance of giving particular attention to fiscal policy and public debt for maintaining macroeconomic stability.

Benigno and Woodford (2006) indicated that monetary policy, on the one hand, has consequences for the intertemporal solvency of the government under a given fiscal policy, so a change in monetary policy requires corresponding changes in fiscal policy, which have welfare consequences if all sources of government revenue are distorted. On the other hand, fiscal decisions have consequences on the supply side of the economy and so it can affect the relationship between inflation stabilization and the output gap. The effects of interest rate policy on debt dynamics are the key to the scenarios of Loyo (1999) and Blanchard (2004) under which tight monetary policy can be inflationary.

On the same line of thinking, Sims (2005) argues that fiscal policies in some countries may not only make the achievement of the inflation target by the CB impossible but also it can be harmful by leading to less stability than might have been achieved through the other policies. This scenario may occur if primary budget surplus does not increase in response to monetary tightening. In such a case, a policy intended to contain inflation when inflation rises above the target by raising nominal interest rate may cause an explosion of the public debt, which ultimately requires large increases in prices. 
Benigno and Woodford (2006), however, agree with this argument under the assumption that the fiscal policy is exogenous and prices are flexible. Nevertheless, they argue that this case is only one limited case among other possible cases that might exist for the optimal monetary policy under a variety of assumptions about the fiscal regime. They emphasize the importance of the cooperation between monetary and fiscal policy. Such cooperation should be focused on the inflation target that the $\mathrm{CB}$ has to hit in the medium to long-term. Such a target of inflation should be determined upon projections about the long run price level, which ensure the government's solvency.

\section{3 FX interventions may undermine the goal of price stability}

As a threshold of switching their monetary policy regimes to the IT, emerging market economies announced floating a FX rate, although practically they apply managed-floating with implicit target for the FX rate. Under managed floating, the CB regularly intervenes in the FX market to maintain the $\mathrm{FX}$ rate at an implicit target. The reason that emerging countries applied a managed floating regime can be referred to the long history of FX turbulence in these countries, the volatility of international financial flows and the vulnerability to the FX rate shocks ${ }^{20}$.

A monetary policy that keeps internal and external targets is either inconsistent or fragile. Besides, the success of hitting the inflation target

\footnotetext{
${ }^{20}$ In fact, most central banks exercise interventions in the FX markets even with the announcement of free-floating FX rate. As long as FX rate is allowed to fluctuate within wide bands the intervention by $\mathrm{CB}$ will be limited and confined only on severe changes. Kamar and Bakardzhieva (2003) define exchange rate system as "fixed" (or managed peg) if the government permitted exchange rate to fluctuate within bands less than $3 \%$, whilst exchange rate system may defined as "floating" (flexible) if exchange rate is permitted to fluctuate at higher than $15 \%$ bands. "Managed bands" (dirty floating) is the case when exchange rate is permitted to fluctuate with bands from $3 \%$ to $15 \%$.
} 
can itself be problematic if CBs have an implicit target for FX rate and/or the $\mathrm{CB}$ cares about FX rate fluctuations. By hitting inflation target the $\mathrm{CB}$ gains higher credibility, consequently domestic inflation moves down but, unfortunately, domestic currency appreciates as well. The reason for such appreciation of domestic currency is the convergence between both domestic and foreign inflation, which lead to real depreciation. With growing the CB's credibility stemming from the success of hitting the target of inflation, expectations about higher real depreciation grow as well, and so domestic currency appreciates. FX rate is also likely to be more volatile in the first stages of applying IT, like the case of the Czech economy (Holub, 2004).

The appreciation of domestic currency and the volatility of FX rate represent a problematic situation for CBs that apply IT. On the one hand, such developments of FX rate threaten both domestic industry and external balance if the $\mathrm{CB}$ does not intervene. On the other hand, the intervention by $\mathrm{CB}$ using short-term nominal interest rate may lead to missing the inflation target $^{21}$. The picture is likely to darken when the CB does not know exactly the equilibrium level of the real exchange rate. Consequently, even if the $\mathrm{CB}$ decided to lose its inflation target by taking the decision of intervention, it will try to return the FX rate to the implicit target, which does not necessarily reflect the equilibrium level of real exchange rate.

\footnotetext{
${ }^{21}$ In the case of the Czech economy, it was not surprised that the periods in which the Czech National Bank (CNB) exercised intervention in the FX market to fix the appreciation of domestic currency were also the same periods in which the CNB lost its target of inflation (Holub, 2004).
} 
Practically, CB intervention may not only be costly, in terms of losing both inflation target and credibility, but is also ineffective $\mathrm{e}^{22}$.

Holub (2004) thinks that CB intervention in the FX market should be confined to the cases in which intervention does not contradict with the primary goal of monetary policy, i.e. price stability. CB intervention, however, can be practiced in the following two cases; (i) If domestic currency appreciates and inflation forecast points below the target and/or output gap is negative. In such a case, a CB can hit the two targets by cutting short-term nominal interest rate. Conversely, if domestic currency depreciates and inflation forecast points higher than the target and/or output gap is positive the $\mathrm{CB}$ can hit the two targets by increasing short-term nominal interest rate. (ii) The intervention as a supplementary tool should not send confusing signals to the market.

\subsection{Asset-price bubbles and the response of the CB}

One of the most difficult challenges to monetary policymakers is how monetary policy under IT should respond to asset-price bubbles, i.e. the case in which financial market valuations become far from reality, thereby assets prices skyrocket. While the $\mathrm{CB}$ is mainly responsible for achieving the goal of price stability via maintaining the CPI-inflation within an announced target, prices of assets including real estates and equities are not included in the CPI. Such an omission is not regarded as a problem in normal times because monetary policy is basically focusing on the development of CPI-inflation over the medium to long-term not in the

\footnotetext{
${ }^{22}$ Disyatat and Galati (2005) studied the effectiveness of the CNB intervention in the foreign exchange market during the period 2001-2002. They found that CNB intervention had some (weakly) statistically significant impact on the spot rate and the risk reversal but this impact was small. They did not find evidence that intervention had an influence on short-term exchange rate volatility.
} 
short-term. However, the debate on whether this concentration of monetary policy on consumer prices alone is appropriate or not always starts when asset-price bubbles occur (Issing, 2009, P.45).

When a bubble inflates and then bursts it bears negative consequences on the economy. Asset-price bubbles influence aggregate demand, driving inflation and output up during the boom and down during the bust, causing a multitude distortion in the economy, and bringing out financial system fragility.

A change in asset prices affects total demand via two sub-channels: Tobin's $q$ and the effect of wealth on consumption. Tobin's $q$ is defined as the market value of firms relative to the replacement cost of capital. The higher the $q$, the higher the market value of the firm and thus the higher the amount of investment that firms can execute. As for the effect of wealth on consumption, this channel is established on the life-cycle hypothesis, in which wealth, including stocks, real estate and any other assets, has a decisive impact on both consumption and saving. Consequently, an increase in the household wealth because of asset-price boom will stimulate household consumption and hence total demand (Mishkin, 2004, 2007). The expansion of both consumption and investment during the boom is swiftly reversed during the bust when a bubble bursts. The collateral used to back loans is overvalued, so when prices collapse it impairs the balance sheets of financial intermediaries.

Literally, the $\mathrm{CB}$ response to asset-price bubbles is basically concentrated on property bubbles not on equity bubbles. Cecchetti (2005, P. 3), guided by the IMF evidence, distinguishes between equity and property price bubbles for several reasons. Firstly, the efficient markets 
hypothesis is more likely to apply to equity than to property. Secondly, equity ownership is highly concentrated among the wealthy people whose consumption decisions are isolated from the fluctuations of the stock market. By contrast, home ownership is spread among populations. Thus, the macroeconomic impact of a boom and crash cycle in property prices might be larger. Thirdly, in many countries housing purchases are highly leveraged, leaving the balance sheets of both households and financial intermediaries exposed to large price declines when a bubble bursts.

How should a CB respond to property bubbles? The answer is controversial. Three fundamental strategies are usually mentioned (Cecchetti 2005, P. 14) ${ }^{23}$ : (i) Respond to the bubbles only insofar as they influence forecasts of future inflation; (ii) React to the fallout of the bubble; and (iii) Lean against the bubble, raising interest rates in an attempt to keep it from enlarging.

The first two strategies are in fact very similar and perhaps the same thing. Both of them are based on an implied assumption that monetary policymakers cannot detect the developments of a bubble when it is building up. If so, they cannot directly react to a bubble by deflating it in the early stages. If monetary policymakers cannot deflate a bubble in the early stages, they do not have another option rather than to react to its consequences. The $\mathrm{CB}$ can react to the consequences of a bubble on both

\footnotetext{
${ }^{23}$ There are also regulatory solutions, e.g. raising margin requirements. Blinder and Reis (2005, P. 71) mentioned that the $\mathrm{CB}$ cannot fight the bubble by simply raising margin requirements. Such a solution may deter small investors but major brokerages and investment banks will not be affected because they always have other options. Kohn (2009, PP. 36-37) guided by the currently crisis, suspects that small or even moderate policy actions would have discouraged the broader speculative developments that have characterized the current episode: overly optimistic expectations of price appreciation, excessive leveraging, and a marked increase in risk-taking by homeowners and investors. He thinks that taking regulatory changes intended to strengthen the financial system — would seem a better course of action under such circumstances.
} 
real GDP and inflation either before it bursts, the first strategy, or after it bursts, the second strategy ${ }^{24}$.

The third strategy is based on two implied assumptions. First, the CB can detect developments of a bubble before it exists or builds up, i.e. the $\mathrm{CB}$ can perceive a bubble with a reasonable degree of accuracy before the market does. As mentioned by Cecchetti (2005, P. 16), Blinder and Reis (2005, P. 68), and Kohn (2009, P. 34) such an assumption is unrealistic or impossible. It is very difficult to identify a bubble in real time because not all the fundamental factors driving asset prices are observable. Thus, any assessment by the CB about whether or not a bubble exists is uncertain. If so, the $\mathrm{CB}$ does not take any action because of fears of negative economic consequences of its decision (Kohn, 2009, PP. 34-35). Secondly, the CB can detect a bubble after it builds up and before it bursts. If so, monetary policymakers, according to the 'lean against the bubble' strategy, have to react to the bubble via the tightening of monetary policy. Greenspan, who prefers a 'mop up after' strategy, thinks that even if we could detect a bubble before it bursts the $\mathrm{CB}$ should not be in the business of bursting a bubble. On the one hand, tightening monetary policy may not be efficient to dent a bubble especially, when investors are expecting a very high

\footnotetext{
${ }^{24}$ Kohn (2009, P. 32) called the reaction of the CB in these two cases a 'conventional strategy'. Where, the $\mathrm{CB}$ does not attempt to use monetary policy to influence the speculative component of asset prices, on the assumption that it has little ability to do so and that any attempt will only result in suboptimal economic performance in the medium run. Instead, the CB responds to asset price movements only to the degree that those movements have implications for future output and inflation. This conventional strategy has been consistent with the practices of most inflation-targeting central banks.
} 
return. On the other hand, tightening monetary policy may bears risks of bursting a non-bubble ( Blinder and Reis, 2005, PP. 66-69) ${ }^{25}$.

One suggestion to this problem is to include the value of existing homes in the price index targeted by the CB (Cecchetti, 2005, P. 17) ${ }^{26}$. Another suggestion mentioned by Issing (2009, P. 49) is that if the CB applies a medium-term horizon for the definition of price stability and adopts an encompassing approach that integrates money and credit in an appropriate way, financial imbalances will implicitly obtain attention. In other words, by achieving financial stability over the short run the $\mathrm{CB}$ can accept a deviation of the rate of inflation from its target in the short run to best maintain price stability over the medium run.

\section{The experience of the Czech Republic, Poland and Brazil under IT}

This section focuses on the following dimensions of the experience of Czech Republic, Poland, and Brazil (CPB) under IT: (i) The factors standing behind the decision of adopting IT in each country. (ii) The level of $\mathrm{CB}$ independence and whether there is a legal obligation for the $\mathrm{CB}$ to finance budget deficit. (iii) The commitment to price stability as a primary goal of monetary policy, price index used to formulate and gauge inflation targets, and the reaction of $\mathrm{CB}$ to supply-side shocks. (iv) The level of

25 Kohn (2009, P. 33) called the reaction of CB in this case an ' extra action' strategy. He thinks that a strategy of extra action might be justified if three tough conditions were met. First, policymakers must be able to identify bubbles in a timely fashion with reasonable confidence. Secondly, a somewhat tighter monetary policy must has a high probability that it will help to check at least some of the speculative activity. Thirdly, the expected improvement in future economic performance that would result from the curtailment of the bubble must be sufficiently great. From this view, the likelihood of ever meeting the three conditions seems remote.

${ }^{26}$ Indeed, there is a wide consensus among economists that the $\mathrm{CB}$ should not target asset prices. 
knowledge of the $\mathrm{CB}$ regarding inflation forecasting and monetary transmission mechanisms.

\subsection{Czech Republic:}

5.1.1 Motives for IT: In December 1997, the Czech National Bank (CNB) adopted the IT regime and in April 1999 it published a comprehensive statement with details about the new strategy. Prior to IT, the monetary policy framework of the CNB was built around exchange rate and monetary targets. From 1991 to February 1996, Czech currency was pegged to a currency basket, and the CNB announced growth targets for broad money (Schaechter, et al. 2000, P. 48). According to Jonas and Mishkin (2003, P. 7), although the rate of inflation has come down after liberalization of prices and devaluation of domestic currency in 1991, it remained stuck at 10 percent and wages and other nominal variables were adjusted to this level. The higher inflation in conjunction with a fixed nominal exchange rate produced real appreciation, which exacerbated a deficit in the current account. The deficit in the current account was widened also because of an inflexible fiscal policy and a tighter monetary policy in terms of high interest rates, which attracted more short-term foreign capitals, fueling further growth of liquidity. The large capital inflows limited the ability of the CNB to achieve domestic stability. With the ongoing liberalization of capital flows and financial market, monetary policy under monetary targets became less effective and insufficient to dampen the growing domestic demand. External imbalance coupled with contagion effects of the Asian crisis triggered speculative attacks on the Czech currency (Koruna) which accelerated the flight of foreign investors from Koruna assets. In an attempt to protect domestic currency, the CNB 
reacted by raising short-term interest rates sharply. Eventually, the CNB decided not to lose a substantial amount of its foreign reserves through defending fixed exchange rate. On May 26, 1997, the government and the CNB decided to float domestic currency.

Immediately after floating the Koruna, monetary policy, still based on monetary targets, could not achieve price stability. Inflation expectations, which had been negatively affected by exchange rate turbulences, were no longer adequately anchored. Furthermore, monetary targeting involved implementation problems where the link between inflation and money supply was unstable and difficult to predict (CNB, 2008).

The decision to introduce IT in the Czech economy was motivated by achieving price stability as a condition for the Czech Republic's prospective membership in the European Union (EU). Indeed, after floating domestic currency and the failure to achieve price stability under the monetary targeting regime, adopting IT was regarded as the only viable option to bring price stability into the Czech economy (Jonas and Mishkin, 2003, PP. 5-7).

According to Schaechter, et al. (2000, P. 49) the initiative to adopt the IT regime was driven by the CNB which eventually gained support by the government to incorporate the long-term monetary strategy into the central document that defines the government's economic policy orientation in the run-up to EU accession. The intention of the $\mathrm{CNB}$ to commit the government to the inflation target is reflected in the timeframe of the target announcements, which gave the government the opportunity to implement them into the state budget. 
5.1.2 CB independence: According to the legislation of the $\mathrm{CNB}^{27}$, the $\mathrm{CNB}$ is independent and the primary objective of monetary policy is to maintain price stability. The CNB's board set instruments of monetary policy and measures of supervision on the financial market. The CNB supports general economic policies that lead to sustainable economic growth without prejudice to its primary objective. The governor of the CNB should submit a report about monetary and financial developments to the parliament at least twice a year for a review. In such an event, the governor is entitled to attend the session of the parliament for clarification. In addition, the CNB should inform the public on monetary developments at least once every three months (articles 1-5).

The president of the Republic appoints the members of the CNB's Board, which consists of seven members, including the governor of the $\mathrm{CNB}$, two deputies of the governor and four other members of the CNB. The Board's members are appointed for a renewable term of six years with a maximum of two consecutive terms in office. The membership of the CNB's Board is prohibited for persons who are members in a legislative body, government body and supervisory bodies of other banks (article 6).

In the course of achieving the primary objective of monetary policy and carrying out the other activities, the CNB should not seek or take instructions from the president of the Republic, the parliament, the government or from any other body. The CNB and the government should inform each other on matters concerning the principles and measures of monetary and economic policy. The minister of finance may attend the meetings of CNB's Board in an advisory capacity and the governor of the

\footnotetext{
${ }^{27}$ Available at: http://www.cnb.cz/m2export/sites/www.cnb.cz/en/legislation/acts/download/ act on cnb.pdf
} 
CNB may attend the meetings of the government in an advisory capacity. The CNB should take a position on proposals presented to the government for considerations of improving its competence (articles 9-11).

5.1.3 Inflation forecasting: During the period of 1998-2002, the CNB applied a forecasting framework that assumed constant interest rates and other key variables, e.g. the exchange rate. The forecasting system during that time comprised of small sets of interrelated equations describing the evolution of some key variables such as inflation, GDP and unemployment. The equations were specified based on economic intuition and were estimated using historical data. Forecasting inflation upon this methodology is confined with the incorporated assumptions in the forecasting process and therefore it did not necessarily reflect the most likely future path of inflation. In addition, this method lacks a clearly identified monetary transmission mechanism. As forecasting upon this methodology lacks accuracy, the decisions of the CNB regarding monetary policy instrument, i.e. the short-term interest rate, incorporated many mistakes, which eventually led to a large deviation between the actual rate of inflation and the targeted inflation rate. Since summer 2002, the CNB used the quarterly projection model (QPM) which abandons the stability assumption of both interest rate and exchange rate. Under the QPM, the future path of both interest rate and exchange rate is predicted along with the other variables in the model. In recent years, the CNB intended to use another advanced model- third-generation ("G3") model - which based on assumptions about the behavior of economic agents- households and corporations (CNB, 2008). 
5.1.4 Price index, inflation targets and escape clauses: In the start of adopting IT, the CNB defined its targets in terms of the so-called 'net inflation'. Net inflation measures changes in the consumer price index (CPI), excluding the movement in regulated prices and first-round impacts of changes to indirect taxes. The net inflation index covers $80 \%$ of the consumer basket (663 items of 754 items are the total items of the CPI at the end of 1997). Inflation based on the net inflation index was targeted mainly because of uncertainty prevailing during that time about the rate and the scale of price deregulation and partly because of limited ability of monetary policy to affect this part of the consumer basket.

The first targets for annual net inflation were set in December 1997. A short-term net inflation target of 5.5\%-6.5\% was defined for December 1998 and a medium-term net inflation target of 3.5\%-5.5\% was specified for December 2000. A short-term target of 4.0\%-5.0\% for December 1999 was announced in November 1998. In April 1999, a long-term target of 1.0\%-3.0\% was set for 2005. The last net inflation target, set in April 2000 was $2.0 \%-4.0 \%$ for December 2001. In April 2001, the CNB decided that it would target the CPI-headline inflation as of 2002. The target announced in April 2001 was set upon agreement with the Government and took the form of a continuous band falling from 3.0\%-5.0\% in January 2002 to 2.0\%-4.0\% in December 2005. In March 2004, the CNB decided that the inflation target as of 2006 would be a point target of $3 \%$ with a tolerance band of \pm 1 percentage point. In March 2007, a new point inflation target of $2 \%$ was announced for January 2010 (CNB, 2008).

After announcing its intention to target the CPI-headline inflation in April 2001, the CNB announced escape clauses for its inflation target. 
Escape clauses included the following cases (Jonas and Mishkin, 2003, 11): (i) Major deviations in world prices of raw materials, energy-producing materials and other commodities. (ii) Major deviations in FX rate that are not related to domestic economic fundamentals and domestic monetary policy. (iii) Major changes in the conditions for agricultural production having an impact on agricultural producer prices. (iv) Natural disasters and other extraordinary events having cost and demand impacts on prices. (v) Changes in regulated prices whose effects on the headline inflation would exceed 1-1.5 percentage points. (vi) Changes in the indirect taxes.

Under the escape clauses, the reaction of the CNB to economic shocks depends on the scale and the duration of it. Shocks with both limited scale and temporary effect do not require intervention by the CNB, although the CNB has to ensure that the deviations from the target are diminishing after a shock. However, economic shocks with both a large scale and permanent effect are a subject of the aforementioned escape clauses. If a shock makes projected inflation deflected from the target, the CNB does not respond to the first-round impacts of it and accepts both the temporary deviation of inflation forecast and, consequently, deviation of future inflation from the target. This is because the intervention during the first round of a shock will exacerbate its negative effects on the real variables. The CNB will respond only to the second-round effects of the shock, i.e. it will prevent a shock passing through to inflation expectations (CNB, 2008).

Did CNB hit its inflation targets? As shown in Figure 1, the CNB missed its targets many times, where the actual rate of inflation was undershot several times. The largest differences between the actual rate of inflation and inflation targets were in periods 1998-1999 and 2002-2003, 
but even in the other periods inflation tended to be below the inflation target.

Figure 1: The fulfillment of inflation targets by CNB

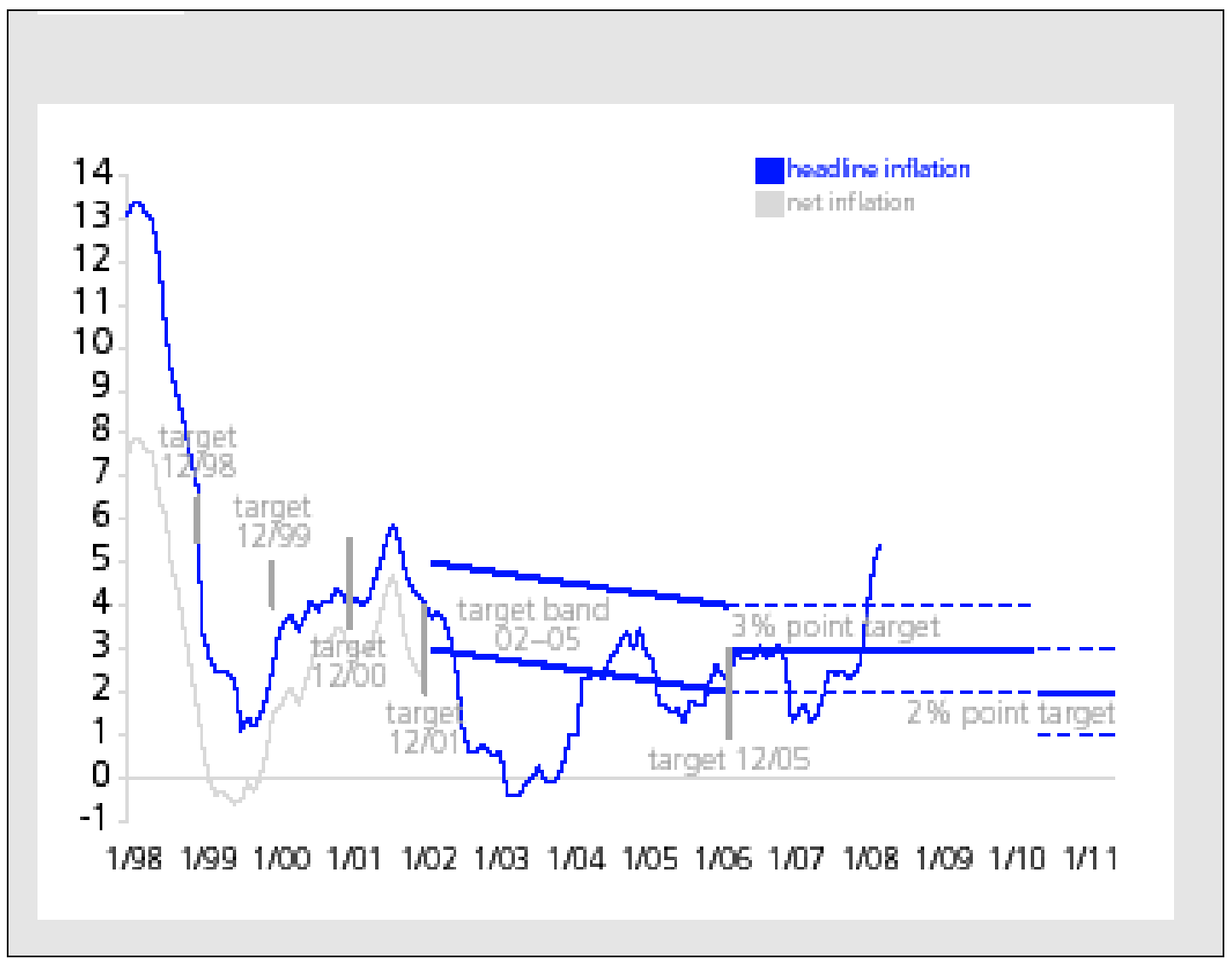

Source: CNB (2008).

Transparently, the CNB (2008) analyzed the reasons behind missing its inflation targets. Many reasons that might have contributed in such an undershooting of inflation targets include: (i) Non-fulfillment of inflation forecasts, (ii) Supply shocks during some periods, e.g. rapid appreciation of Koruna, overproduction of agricultural commodities, and (ii) Inadequate assessment of forecast risks by the MPC.

According to the CNB's explanation, the non-fulfillment of inflation forecasts, owing to a combination of supply shocks and imperfections in 
the forecasting system, was the main reason behind missing most inflation targets.

\subsection{Poland}

5.2.1 Motives for IT: In September 1998 the National Bank of Poland (NBP) announced its intention to adopt IT regime but the actual start of full-fledged IT can be marked by the widening of the exchange rate band in March 1999 (Schaechter, et al. 2000, 51).

In 1990, domestic currency (Zloty) was pegged to a currency-basket. The high level of inflation along with a fixed exchange rate resulted in both real appreciation and eroding external competitiveness. Therefore, a crawling peg was introduced in October 1991. The large capital inflows in 1994 and 1995 mainly because of liberalizing capital account forced the authorities to announce a crawling band in May 1995. In May 1996, the NBP widened the crawling exchange rate band to \pm 7 percent. Upward pressure on domestic currency continued, the NBP widened the band again to \pm 10 percent in February $1998, \pm 12.5$ percent in October 1998 and finally to \pm 15 percent in March 1999. In April 2000, Poland abandoned the exchange rate band and switched to a managed floating FX rate (Jonas and Mishkin 2003, PP. 11-12). According to Schaechter, et al. (2000, P. 51), successive widening of bands did not prevent accumulative real appreciation that contributed to the worsening of the current account.

However, introducing IT in Poland was motivated by achieving price stability that represented a key element for the accession to the EU.

5.2.2 CB independence: According to the legislation of the $\mathrm{NBP}^{28}$, maintaining price stability represents the fundamental objective of

\footnotetext{
${ }^{28}$ Available at: http://www.nbp.pl/en/aktyprawne/theactonthenbp.pdf
} 
monetary policy. At the same time, the NBP should act in support of the government's economic policies in a way that does not contradict its fundamental objective (article 3). The Monetary policy council (MPC) is responsible for formulating and applying monetary policy. The MPC consists of nine member specialists in the field of finance under the chairmanship of the governor of NBP. Both governor and members are appointed by the president of the republic for a renewable term of six years with a maximum of two consecutive terms of office. The decision of the MPC is taken upon the majority of votes (articles 9, 13 and 16).

The relationship between the NBP and the government includes the following dimensions: (i) The NBP supplies the government with both monetary policy guidelines and reports on the performance of monetary policy and the situation within the banking system. (ii) The NBP collaborates with the minister of finance in developing central government financial plans. (iii) the NBP presents its opinion on draft legislations related to economic policy. (iv) the NBP presents its opinion on draft legislations concerning the operations of banks and other legislation of significance to the banking system. (v) The governor of the NBP may attend the cabinet meetings. (vi) Setting exchange rate policy and the procedures of setting the exchange rate of Zloty against foreign currencies are the responsibility of the cabinet council after consultation with the MPC (articles 21, 22 and 24).

5.2.3 Inflation forecasting: Due to limits and uncertainty related to economic transition, like short time series and lack of well-documented stylized facts, the first models developed in the NBP were relatively simple. In 2000, two structural econometric models emerged as the main 
tools of preparing regular inflation projections. The first one, NSA, referred to neo-Keynesian mechanisms and focused on the relationship between inflation and aggregate demand while the second, MSMI, incorporated also some supply-side element. In 2004, both models were judged mature enough to use them in official projections. One of the shortcomings of such a combined approach is the inconsistent outcomes where NSA and MSMI were substantially differed in terms of size, structure and variables.

A new project was launched, aimed at constructing a new and more comprehensive forecasting tool. The new model, the ECMOD, was completed in 2005 and used since then as the main vehicle for generating official NBP projections. The ECMOD incorporated both supply and demand side of the economy and was allowed to analyze economic developments and construct relatively sophisticated scenarios.

Structural shifts in the Polish economy lead to regular refinements of the ECMOD by adding new blocks and changing its structure, which eventually generated a new and an identical model called NECMOD. The NECMOD is a large-scale quarterly macroeconomic model comprising all main groups of macro-categories in the economy including GDP components, costs and prices, labor market, external sector, fiscal variables and interest rates. The model is detailed enough to serve a wide range of purposes and address policy relevant questions, including forecasting and simulation exercises (Budnik, et al., 2008).

5.2.4 Price index, inflation targets and escape clauses: the NBP is formally targeting the CPI-headline inflation. The reason for targeting CPI inflation is that it has been extensively used in Poland after the period of transition and therefore it represents the most noticeable measurement of 
inflation. NBP uses also other heuristic indices for inflation, e.g. core inflation and producer price index.

During the period of 1999-2003, the NBP chose to target a band rather than a point. According to the medium-term strategy of monetary policy for the years 1999-2003, established in 1998, the strategic monetary policy target determined by the MPC was to bring inflation down to below $4 \%$ by the end of 2003. The short-term inflation target that was determined for the year 1999, set in the range of 6.6\%-7.8\%, was not achieved where the CPIinflation stood at $9.8 \%$. In addition, in the year 2000 the annual inflation target overshot, where the inflation target was $5.4 \%-6.8 \%$ whereas the CPI inflation rate stood at $8.5 \%$. For the third year in succession, the NBP lost its target but this time was undershooting, where the inflation target was $6 \%-8 \%$ for the year 2001 but actual CPI inflation was 3.6\%. For the year 2002 , the target was $5 \%$ with permissible band of \pm 1 percentage point. Again, the actual rate was undershot where the CPI inflation rate was 1.9\% in May 2002.

Starting from 2004, the MPC adopted a permanent inflation target at $2.5 \%$ with a symmetrical tolerance range for deviations of \pm 1 percentage point. According to the NBP's clarifications for the new target: (i) Permanent inflation target means that it refers to inflation measured as a year-on-year change in consumer's prices of goods and services in each month compared to the corresponding period of the preceding year. (ii) The NBP intends to maintain inflation close to the target of $2.5 \%$ and not only within the tolerance range. (iii) As the occurrence of shocks in the economy is inevitable, the stance of NBP depends on the scale and duration of such shocks. The NBP responds to such deviations from the inflation target, 
which deem temporary and lay within the tolerance range around the target. In the case of shocks viewed as leading to a permanent deviation from the inflation target, the NBP adjusts its monetary policy accordingly ${ }^{29}$.

During the periods of 2004-2008, the NBP missed its inflation targets several times ${ }^{30}$. According to the explanations of the NBP, it was the supply shocks, e.g. changes in food and oil prices that were mostly responsible for such deviations ${ }^{31}$.

\subsection{Brazil}

5.3.1 Motives for IT: beginning from July 1999, the Central Bank of Brazil (BCB) formally applied the IT regime. The adoption of IT came upon the aftermath of financial crisis, which forced the BCB to abandon the crawling exchange rate peg and float its currency in January 1999.

Brazil began its economic reform and structural adjustment program in mid-1994. During less than three years, Brazil was able to successfully bring down the rate of inflation to one digit. Under a stabilization program, a crawling exchange rate peg was used as a nominal anchor of monetary policy. Beside its negative consequences on the government debt, the higher levels of short-term interest rates oriented mainly to attract foreign capitals led to appreciation of domestic currency and hence deteriorated trade balance. With the occurrence of financial crises during the period 1995-1998, particularly the Russian default on its debt in August 1998, the exchange rate came under pressure. Domestic currency incurred

\footnotetext{
29 See: NBP, Monetary Policy Implementation (different years), and Monetary Policy Guidelines (different years). Available at: http:// www.nbp.pl/ Homen.aspx?f $=$ en/ aktyprawne/ustawa.html

${ }^{30}$ See: NBP, Inflation Report (different years). Available at: http://www.nbp.pl/Homen.aspx?f=en/publikacje/raport inflacja/raport inflacja.html

${ }^{31}$ The NBP always mentions some reasons connected to the supply shocks to explain the reasons for missing inflation targets, but they rarely mention something connected to the possibility of the forecasting flaws or an inadequate assessment of forecasts by the MPC.
} 
speculative attacks, which led to capital outflows. In an attempt to defend domestic currency and halt capital outflow, the BCB increased the shortterm nominal interest rate along with tightening fiscal policy. Although the nominal interest rate reached to $39 \%$ it did not stop the panic of possible further depreciation of domestic currency, thus capital outflow continued. These events forced the BCB to float its currency in January 1999. In February 1999, domestic currency plunged from 1.20 to 2.15 to the US dollar. Under the pass-through effect estimated by 30-40 percent, the threat of hyperinflation and deep recession became the most likely future path for Brazilian economy, given Brazil's history of hyperinflation.

A decisive action had to be taken by the $\mathrm{BCB}$ to calm down the nervous financial markets and mitigate the panic. In the first place, the expectations that an inflation hike could bring the real rates of return on public debt instruments to a negative range were the first to be attacked. The BCB decided to increase the short-term interest rate from $39 \%$ to $45 \%$. In addition, individuals' expectations about the future path of inflation had to be anchored. Taking into account that a return back to the crawling peg was considered at that time as unpractical solution, the $\mathrm{BCB}$ decided to continue with the choice of floating. Consequently, a nominal anchor for monetary policy became urgently needed. A policy based on the monetary aggregates did not seem feasible, particularly with growing uncertainties inherent in the crisis sweeping through the Brazilian economy. In such circumstances, a policy without an explicit nominal anchor was also unfeasible. The $\mathrm{BCB}$ decided to mitigate the crisis by anchoring inflationary expectations through a transparent commitment with a target for inflation. Therefore, the BCB announced in March 1999 its intention to 
move to IT by the end of June 1999 and its goal is to reduce inflation by the end of 1999 to single digits (Schaechter, et al., 2000; Fraga, 2000; Arestis, et al., 2008).

An important thing in the Brazil's experience is that they began to prepare for IT during a limited time-period, i.e. from March to June 1999. According to Bogdanski, et al. (2000), the BCB was not granted formal instrument independence until that date, forecasting capabilities were very limited and the majority of BCB staff did not know much about IT. The $\mathrm{BCB}$ was the initiator regarding the adoption of the IT regime. Convincing the president and other members of government particularly the minister of finance via sound arguments was important for $\mathrm{BCB}$ to obtain legal independence. A research department was created at the end of March 1999. Designing the institutional framework and modeling monetary transmission mechanisms, by the Bank staff supported by the IMF, began after the establishment of the research department. The legal framework of IT implementation was declared upon the Decree No. 3088 of June 21, 1999 issued by the President of Brazil.

5.3.2 CB independence: According to Bogdanski, et al. (2000), Barbosa-Filho (2007), and Arestis, et al. (2008), the national monetary council $(\mathrm{CMN})$, that includes the minister of finance, minister of planning and the governor of the $\mathrm{BCB}$ sets inflation targets and its corresponding intervals of tolerance proposed by the minister of finance. Members of the CMN are appointed by the president of Brazil and do not have fixed mandates. From 2000 onward, inflation targets and their corresponding intervals have to be set for the next two years by no later than June 30 every year. The CMN determines price index, first proposed by the 
minister of finance, which will be used for the purposes of calculating and assessing inflation targets. The $\mathrm{CMN}$ is also responsible for approving norms related to monetary and exchange rate policies as well as financial system regulation.

The MPC of $\mathrm{BCB}$ is responsible for implementing monetary policy using appropriate tools, e.g. determines the level of the CB's base interest rate (SELIC) and occasionally changes in banks' reserve requirements. The governor of the $\mathrm{BCB}$ has the right to alter the SELIC anytime between regular meetings of the MPC (once per month) in the direction of the bias determined by it. If the governor wants to change the interest rate in the opposite direction of the bias an extraordinary meeting of the MPC has to be held to take the decision. The inflation target is considered to be fulfilled when the accumulated inflation, measured by changes in the price index during the period January-December every year, lies inside the tolerance intervals of the target. In case of actual inflation breaching the target, the governor of the $\mathrm{BCB}$ has to write an open letter to the minister of finance explaining the reasons for that, the measures proposed to bring actual inflation back to the target and the period through which these measures are expected to have an effect.

5.3.3 Inflation forecasting: During the interim period of preparation for introducing IT in Brazil, the research department of the BCB backed by the IMF and some other central banks developed a set of tools to support the decision-making process of the MPC. According to Bogdanski, et al. (2000), these tools included: (i) A Small-scale structural model for transmission mechanisms of monetary policy. Upon the estimation results of this model, the aggregate demand channel of monetary transmission 
mechanism takes 6 to 9 months to produce significant effect on domestic inflation. In addition, changes in nominal interest rate have contemporaneous affects on the nominal exchange rate, and the later have a contemporaneous effect on the domestic inflation. (ii) Short-term inflation forecasting models (VAR and ARMA models). These models are used to generate short-term forecasts for inflation rate. Beside using these forecasts for comparative purposes with the other forecasts generated by the structural model, it is also used as inputs for the structural model to estimate future paths of both the real and nominal interest rate.

5.3.4 Price index, inflation targets and escape clauses: the price index used for gauging inflation targets is the headline CPI. The use of the headline index rather than a core inflation index was essential for credibility reasons where Brazilian society has experienced several manipulations of price indices in the past (Bogdanski, et al., 2000). This explains why the CMN decided not to exclude any elements of the CPI for reasons pertaining credibility. Nevertheless, the CMN did not announce escape clauses for its inflation targets. The use of CPI headline inflation and the absence of escape clauses justify the adoption of a relatively wide tolerance interval around the central target, two-percentage points.

As shown in Table 1, inflation targets were inside the tolerance intervals for the years 1999 and 2000. In 2001 and 2002, actual inflation overshot the targets. According to Arestis, et al. (2008) and the explanation of the governor of the $\mathrm{BCB}$ through an open letter ${ }^{32}$, the reasons were because of external and domestic economic shocks, e.g. the domestic energy crisis in Brazil, negative consequences of September 11 events in

\footnotetext{
${ }^{32}$ Available at: http://www.bcb.gov.br/?COMMITTEE
} 
2001 and the political presidential crisis in 2002. Besides, in 2003 the actual rate of inflation overshot the adjusted target of 4.0\%, and in 2004 the BCB hit the target only after it had been widened. The high inflation in 2003 is referred to the inflation inertia while the high inflation in 2004 is explained by the increase of the administrative prices.

Table 1: Inflation targets in Brazil

\begin{tabular}{|c|c|c|c|c|c|c|}
\hline Year & Regugulation & Date & Targeter (lon) & $\begin{array}{l}\text { Tolerance } \\
\text { lntervals }\left(p_{0}, p_{1}\right)\end{array}$ & $\begin{array}{c}\text { Upper and Lowar } \\
\text { Limitits }(\%)\end{array}$ & 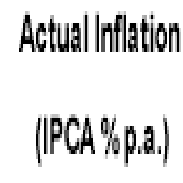 \\
\hline 1990 & & & 8 & 2 & 6.10 & 894 \\
\hline 2000 & Resolution 2,615 & $630 / 1990$ & 6 & 2 & 48 & 597 \\
\hline 2001 & & & 4 & 2 & 2.6 & 7.67 \\
\hline 2002 & Resolution 2,744 & $6 / 28 / 2000$ & 35 & 2 & 1.5 .5 .5 & 1253 \\
\hline \multirow{2}{*}{$2003^{31}$} & Resolution 2,842 & $6 / 28 / 2001$ & 325 & 2 & 1.25 .5 .25 & \\
\hline & Resolution 2,972 & 61272002 & 4 & 25 & 1.56 .5 & 9.30 \\
\hline \multirow{2}{*}{$2004^{11}$} & Resolution 2,972 & $627 / 2002$ & 375 & 25 & 1.25 .6 .25 & \\
\hline & Resolution 3,108 & $6 / 25 / 2003$ & 5.5 & 25 & 38 & 760 \\
\hline 2005 & Resolution 3,108 & 62520003 & 4.5 & 2.5 & 2.7 & 569 \\
\hline 2006 & Resolution 3,210 & 63002004 & 4.5 & 2 & 25.6 .5 & 3.14 \\
\hline 2007 & Resolution 3,291 & $623 / 2005$ & 4.5 & 2 & 25.6 .5 & 4.46 \\
\hline 2008 & Resolution 3,378 & 62902006 & 4.5 & 2 & 25.5 .5 & \\
\hline 2009 & Resolution 3,463 & 62662007 & 4.5 & 2 & 256.5 & \\
\hline 2010 & Resolution 3,584 & $177 / 2000$ & 4.5 & 2 & 256.5 & \\
\hline
\end{tabular}

Source: BCB, available at; http://www.bcb.gov.br/pec/metas/InflationTargetingTable.pdf

According to Barbosa-Filho (2007), exchange rate has a greater effect on domestic prices in Brazil and that is why the $\mathrm{BCB}$ was implicitly 
targeting FX rate in an asymmetric way through dirty floating. Where, the $\mathrm{BCB}$ was fighting devaluations of domestic currency and, at the same time, tolerating devaluations in order to meet the inflation target. Therefore, the success of hitting inflation targets was allowed when exchange rate dynamics coped with the BCB's efforts to keep inflation under control. In addition, the high real interest rate imposed expansionary pressures on net public debt.

\section{Lessons from the experience of some emerging market economies}

Different lessons can be drawn from the experience of the CPB under IT:

6.1 These countries were seriously keen on, and willing to achieving the goal of price stability: the real intention to achieve price stability represented the stimulus behind adopting IT in these countries. Because such intention was real, it was swiftly translated into tangible steps on the ground. From Brazils experience, when the $\mathrm{BCB}$ and the government became convinced with the adoption of IT as a means to achieve price stability, both preparation and implementation of IT had been accomplished during a very limited time, i.e. during the period from March to June of the year 1999 .

\subsection{IT is adopted to serve as a new nominal anchor for monetary} policy: After floating their currencies, $\mathrm{CPB}$ found that the IT regime is the only viable option to achieve the goal of price stability upon forwardlooking bases. A monetary policy regime without an explicit nominal anchor, just do it strategy, was not an appropriate alternative to tie down individuals' expectations about the future path of inflation especially as CBs in these countries did not have a track record of credibility during that 
time. In addition, a monetary targeting regime was not also an appropriate alternative especially after liberalizing capital flows and financial markets, which undermined the relationship between money supply and price level. Moreover, managing monetary policy under targeting foreign exchange rate regime no longer represents a suitable option.

Why did CPB float the FX rate? Indeed, CPB were forced to float their currencies in order not to lose an influential part of their foreign reserves on the aftermath of economic crises. The decision of floatation came on the backdrop of speculative attacks on domestic currency triggered by both the Asian crisis and external imbalances of current accounts. The imbalances of current accounts emerged because of pegging the FX rate in conjunction with high domestic inflation, thereby real appreciation occurred.

6.3 IT is problematic if pass-through effect is high: A problematic issue here is that, while the CB has to be credible regarding the announced inflation target a devaluation of domestic currency causes actual inflation to deviate from the target when the pass-through effect is high. To maintain credibility, the $\mathrm{CB}$ has to determine in advance escape clauses for its targets. As mentioned, the CNB announced escape clauses pertaining to the FX rate after targeting CPI-inflation. Conversely, the BCB did not announce escape clauses but used a wide tolerance interval for its inflation target. Because of the high pass-through effect, the BCB continued targeting the FX rate implicitly in an asymmetric way, i.e. fighting devaluation and tolerating revaluation.

6.4 Missing inflation targets was generally because of forecast's flaws: despite escape clauses were defined explicitly in the case of the CNB and implicitly in the case of the NBP, CBs in both countries missed 
inflation targets several times. In its assessment of ten years of IT, the CNB concluded that forecast flaws were responsible for missing most of its targets. Although the NBP was less transparent regarding the real reasons behind missing inflation targets, it applied similar steps to the CNB by improving its ability for forecasting through building up more sophisticated models and improving its knowledge about monetary transmission mechanisms.

6.5 CB independence is factual. According to the aforementioned criterion about factual independence of the $\mathrm{CB}, \mathrm{CBs}$ in $\mathrm{CPB}$ possess legal instrument independence, absence of governments' representatives in the MPC as voting members, and absence of fiscal dominance in the form of no obligation for the $\mathrm{CB}$ to finance budget deficit.

6.6 Factual independence of the $C B$ was not, mostly granted by the government but proposed by CBs. CBs, especially in Czech Republic and Brazil, were the initiators to propose IT to the government. Perhaps the CNB did not spend much effort to convince the government for the adoption of IT because the government was mainly motivated by the accession to the EU but the $\mathrm{BCB}$ played an active role to convince the government for the adoption of IT.

6.7 CBs in CPB did not possess all prerequisites for IT in the early days of adopting IT. As mentioned, $\mathrm{CBs}$ in $\mathrm{CPB}$ were factually independent and they were serious about achieving price stability. Nevertheless, some of them practiced intervention in the FX market at least during the first stages of adopting IT, e.g. the CNB and BCBs. Besides, forecasting capabilities including sophisticated models for both inflation forecasting and inflation projection and the knowledge about both timing 
and effect of monetary transmission mechanisms were not satisfactory in the first stages of adopting IT.

\section{The availability of prerequisites of IT in Egypt compared with CPB}

This section utilizes the experience of the CPB by comparing the current position of Egypt to these countries in their early days of adopting IT. Such a comparison will help us to gauge whether Egypt has the capacity to apply IT. In addition, by comparing the current position of Egypt to that which was prevailing in the CPB during adopting IT, we may detect factors that Egypt has to take into account in the course of transforming its monetary policy regime to a full-fledged IT regime.

As a criterion of the capacity to adopt IT, the study focuses on the availability of preconditions of IT in Egypt. As mentioned, three preconditions are frequently demanded for a successful application of IT; factual independence of the $\mathrm{CB}$, commitment to price stability as a primary goal of monetary policy, and Forecasting capabilities. The study presumes that the political intention of the government of Egypt is supportive to the adoption of IT as a means of achieving the goal of price stability once prerequisites of IT have been accomplished.

\subsection{Factual independence of the CB}

As mentioned, factual independence of a $\mathrm{CB}$ hinges on three basic pillars; (i) Having legal instrument independence, (ii) Non-existence of the government's representatives as voting members in the MPC, and (iii) Absence of fiscal dominance, including no obligation for the $\mathrm{CB}$ to finance the budget deficit and domestic financial markets should have enough depth to absorb placements of public debt. We may explore factual 
independence of the $\mathrm{CBE}$ by considering the availability of the above elements and compare it to CPB.

7.1.1 Legal instrument independence of the CBE: similar to $\mathrm{CPB}$, the new law of the CBE, the banking sector, and the money (henceforth the new legislation) determined the primary objective of monetary policy to be achieving both price stability and banking system soundness within the context of the general economic policy of the state ${ }^{33}$. The CBE sets, in agreement with the government, objectives of monetary policy through a coordinating council formed by a decree of the president of the Republic ${ }^{34}$.

The governor of the CBE is appointed by a decree of the president of the Republic upon his/her nomination by the prime minister for a renewable term of four years. The resignation of the governor is accepted by a decree of the president of the Republic.

Like $\mathrm{CBs}$ in $\mathrm{CPB}$, the $\mathrm{CBE}$ possesses instrument independence where the board of directors or MPC is the authority responsible for realizing the objectives of monetary policy through implementing monetary, credit and banking policies. Particularly, MPC determines instruments of monetary policy to be used, the structure of credit and discount rates and both regulatory and supervisory standards of banking system.

\footnotetext{
${ }^{33}$ Law No. 88 of the year 2003 amended by law No. 162 of the year 2004 and Law No. 93 of the year 2005 is known as the new law of the CB, the banking sector, and the money. Available at: http://www.cbe.org.eg/public/Banking\%20Laws/Law\%2088,\%20amendments, \%2013-72005.pdf

${ }^{34}$ According to the presidential decree No. 7 for 2005, the coordinating council of monetary Policy (CCMP) is responsible for determining the targets of monetary policy in a way that realizes price stability and banking system soundness within the general economic policy of the state. It is headed by the prime minister, formed of 12 members; 6 of whom are independent from the private sector and international organizations, 3 from the CBE (the governor and the two deputies) and 3 ministers from the government (ministers of finance, planning, and investment).
} 
7.1.2 The government's representatives in the MPC: unlike to $\mathrm{CPB}$, the MPC of the CBE includes the government's representatives as voting members. According to law no. 88 of 2003, the MPC of the CBE consists of fifteen members. They are; the governor of the CBE and his two deputy governors, the chairman of capital market authority, three members representing the ministries of finance, planning and foreign trade and eight experts in monetary, financial, banking, legal and economic affairs designated by the president of the republic for a renewable term of four years.

Recently, law no. 125 issued on 8 Oct., 2011, intended to amend certain provisions of law no. 88 of 2003 including the MPC's members. The new board comprised nine members, instead of fifteen. They are; the CBE governor and his two deputy governors, the chairman of the Egyptian financial supervisory authority, a representative of the ministry of finance, and four members with expertise in financial, economic, and legal matters.

Although these changes represent an important step on the right direction it is not sufficient to prevent conflict of interests of the MPC's members. The exclusion of the two members representing the ministries of planning and foreign trade can prevent conflict between price stability objective and FX rate and real growth objectives. But, maintaining a representative member of the ministry of finance inside the MPC is, still, a source of conflict between price stability objective and government's needs to finance budget deficit, especially with the obligation of the $\mathrm{CBE}$ to finance budget deficit.

7.1.3 The obligation of $\mathrm{CB}$ to finance budget deficit: Unlike to $\mathrm{CBs}$ in $\mathrm{CPB}$, the $\mathrm{CBE}$ has to extend finance to the government upon its request 
to cover a seasonal deficit in the general budget with an amount not exceeding $10 \%$ of the average revenues of the state budget during the three previous years. The term of such financing is three months renewable for other similar periods, with a maximum of twelve months. The conditions concerning this financing are determined upon an agreement between the ministry of finance and the CBE.

Comparing the current economic performance in Egypt to its counterparts in $\mathrm{CPB}$ during the periods preceding the adoption of IT may sheds light on the competence of Egypt to apply IT. Theoretically, high real GDP growth is expected to be negatively associated with the adoption of IT. Since high GDP growth reflects a success of macroeconomic policies, then there is little incentive for the authority to adopt IT. Similarly, large GDP variability is associated with dissatisfaction with economic policy and hence gives more incentive for adopting IT. In addition, the higher the rate of both inflation and its variability the more likely that a country will adopt IT (Hu, 2003, PP. 10-11). 
Table 2: Some indicators about macroeconomic performance for both Egypt and $\mathrm{CPB}$

\begin{tabular}{|c|c|c|c|c|c|c|c|}
\hline \multirow[t]{2}{*}{ Country } & \multirow{2}{*}{$\begin{array}{c}\text { Time of } \\
\text { adopting } \\
\text { IT }\end{array}$} & \multicolumn{3}{|c|}{ CPI annual inflation } & \multicolumn{3}{|c|}{$\begin{array}{c}\text { The rate of growth } \\
\text { of GDP }\end{array}$} \\
\hline & & $\mathbf{M}$ & $\mathbf{S}$ & $\mathbf{V}$ & $\mathbf{M}$ & $\mathbf{S}$ & $\mathbf{V}$ \\
\hline $\begin{array}{l}\text { Czech Republic } \\
\text { (1995-1997) }\end{array}$ & $\begin{array}{l}\text { December } \\
1997\end{array}$ & 8.8 & 0.31 & 0.35 & 3.2 & 3.57 & 1.12 \\
\hline $\begin{array}{l}\text { Poland (1995- } \\
\text { 1998) }\end{array}$ & $\begin{array}{l}\text { March } \\
1999\end{array}$ & 18.63 & 7.07 & 0.379 & 6.3 & 0.96 & 0.15 \\
\hline $\begin{array}{l}\text { Brazil (1995- } \\
\text { 1998) }\end{array}$ & $\begin{array}{l}\text { End of } \\
\text { June } 1999\end{array}$ & 22.96 & 29.16 & 1.27 & 2.48 & 1.87 & 0.75 \\
\hline \multicolumn{2}{|c|}{ Egypt(1995-1998) } & 7.85 & 5.45 & 0.694 & 4.78 & 0.61 & 0.128 \\
\hline \multicolumn{2}{|c|}{ Egypt (2007-2011) } & 12.14 & 3.6 & 0.29 & 5.17 & 2.2 & 0.42 \\
\hline \multicolumn{2}{|l|}{ CZ (2007-2011) } & 2.73 & 2.14 & 0.78 & $3.3^{*}$ & 3.88 & 2.27 \\
\hline \multicolumn{2}{|c|}{ Poland (2007-2011) } & 3.5 & 0.89 & 0.25 & 4.35 & 1.88 & 0.43 \\
\hline \multicolumn{2}{|c|}{ Brazil (2007-2011) } & 5.17 & 1.1 & 0.21 & 4.2 & 3.09 & 0.73 \\
\hline
\end{tabular}

$\mathrm{M}=$ Mean, $\mathrm{S}=$ Standard deviation, $\mathrm{V}=$ Coefficient of variation $(\mathrm{S} / \mathrm{M})$

*After excluding the extreme negative value of real GDP growth in 2009 (-4.69) which can be attributed to world economic crises.

Source: Collected and calculated by the author from the World Bank, World Development Indicators

Table 2 exhibits inflation and real GDP growth in both Egypt and CPB. The rate of inflation in Egypt during the period 1995-1998 was lower than that of CPB but, unfortunately, it has been worsened during the period 2007-2011by hitting two digits (12.14) and recording higher level than that of CPB. Despite of this, the level of inflation in Egypt in the last periods is still lower than its counterparts in Poland and Brazil in the start of their adoption of IT. In addition, the coefficient of variation of inflation in Egypt 
during the last period (0.29) is better than that of CPB during the period 1995-1998.

Concerning the rate of growth of real GDP, both the level and the coefficient of variation of real GDP growth in Egypt in the period 20072011 exhibit a better shape than that of CPB in the start of adopting IT.

Table 3: Some indicators about financial depth and symptoms of fiscal dominance

\begin{tabular}{|c|c|c|c|c|c|c|c|c|c|c|}
\hline \multirow[t]{2}{*}{ Country } & \multirow[t]{2}{*}{$\begin{array}{l}\text { Time of } \\
\text { adopting } \\
\text { IT }\end{array}$} & \multicolumn{3}{|c|}{$\begin{array}{c}\text { Cash surplus/ } \\
\text { deficit (\% of } \\
\text { GDP) }\end{array}$} & \multicolumn{3}{|c|}{$\begin{array}{c}\text { Claims on } \\
\text { government } \\
\text { (annual growth as } \\
\% \text { of } \mathrm{M} 2)\end{array}$} & \multicolumn{3}{|c|}{$\begin{array}{c}\text { Financial depth = } \\
\text { M2 / GDP (\%) }\end{array}$} \\
\hline & & $\mathbf{M}$ & $\mathbf{S}$ & $\mathbf{V}$ & $\mathbf{M}$ & $\mathbf{S}$ & $\mathbf{V}$ & $\mathbf{M}$ & $\mathbf{S}$ & $\mathbf{V}$ \\
\hline $\begin{array}{l}\text { Czech } \\
\text { Republic } \\
(1995-1997)\end{array}$ & $\begin{array}{l}\text { December } \\
1997\end{array}$ & -1.33 & 0.57 & 0.43 & -1.33 & 2.88 & 2.1 & 63 & 1 & 0.01 \\
\hline $\begin{array}{l}\text { Poland(1995- } \\
\text { 1998) }\end{array}$ & March 1999 & - & - & - & 4.25 & 1.5 & 0.35 & 30.5 & 2.64 & 0.08 \\
\hline $\begin{array}{l}\text { Brazil (1995- } \\
\text { 1998) }\end{array}$ & $\begin{array}{l}\text { End of June } \\
1999\end{array}$ & $-2^{1}$ & 2.8 & 1.4 & 21.75 & 17.46 & 0.8 & 32.75 & 4.7 & 0.14 \\
\hline \multicolumn{2}{|c|}{$\operatorname{Egypt}(1995-1998)$} & $0^{2}$ & - & - & 2.25 & 2.2 & 0.98 & 74 & 1.8 & 0.02 \\
\hline \multicolumn{2}{|c|}{ Czech Republic (2007-2011 } & -3.5 & 2.38 & 0.68 & 1.4 & 2.9 & 2.1 & 68.6 & 5.54 & 0.08 \\
\hline \multicolumn{2}{|c|}{ Poland(2007-2011) } & -4 & 2 & 0.5 & 2.6 & 4.03 & 1.55 & 50.6 & 4 & 0.07 \\
\hline \multicolumn{2}{|c|}{ Brazil (2007-2011) } & -2.33 & 1.5 & 0.65 & 3.4 & 2.88 & 0.84 & 62.8 & 4.8 & 0.07 \\
\hline \multicolumn{2}{|c|}{$\operatorname{Egypt}(2007-2011)$} & -6.5 & 1.2 & 0.19 & 7 & 6.6 & 0.94 & 80.4 & 5.72 & 0.07 \\
\hline
\end{tabular}

$\mathrm{M}=$ Mean, $\mathrm{S}=$ Standard deviation, $\mathrm{V}=$ Coefficient of variation (S/M)

${ }^{1}$ calculated for the periods 1997-1998. ${ }^{2}$ calculated for the periods 1995-1997.

Source: Collected and calculated by the author from the World Bank, World Development Indicators.

Table 3 delivers another piece of information pertaining the financial depth and symptoms of fiscal dominance. Williamson and Mahar (1998) 
suggest that financial depth, measured by the M2/GDP ratio is a helpful indicator in assessing the financial system efficiency in mobilizing funds. In other words, with a high M2/GDP ratio the financial system can afford movements in nominal interest rates to mop up liquidity that has been provided at the previous discount window.

According to this indicator, as shown in Table 3, Egypt exhibits a better outlook than CPB even during the period 1995-1998 ${ }^{35}$. Concerning claims on government and cash deficit of the general budget, both of them incorporated substantial increase in Egypt during the period 2007-2011 comparing to the period 1995-1998, and they came higher in Egypt than in the CPB, especially in the period 2007-2011. In addition, while claims on government were dwindling in both Poland and Brazil during the two periods, the opposite was true in Egypt.

Indeed, the main shortcoming in macroeconomic policy in Egypt is the performance of the general budget. Although the budget deficit in Egypt (\% of GDP) was better than in Czech Republic and Brazil during the period 1995-1998 it has been exacerbated during the periods 2007-2011, as shown in Table $3^{36}$. The high budget deficit, coupled with both formal obligation of the CBE to finance the budget deficit and the existence of government's representatives in the MPC as voting members undermine the factual independence of $\mathrm{CBE}$ and cast skeptics on the competence of the $\mathrm{CBE}$ to achieve price stability.

\footnotetext{
${ }^{35}$ This ratio should be interpreted cautiously. Otherwise, why is this ratio higher in Egypt than in CPB? One reason for this, as mentioned above, is that the CBE stands ready to finance the budget deficit via the issuing of new money. With high budget deficit and the contribution of the CBE in financing budget deficit, M2 goes up and hence M2/GDP ratio is higher.

${ }^{36}$ During the two fiscal years 2009/2010 and 2010/2011, the overall budget deficit to GDP (\%) grew from $8.1 \%$ to $9.5 \%$, respectively, and gross domestic public debt to GDP (\%) inched up from 73.6 to 76.2, respectively (CBE, annual report 2010-2011).
} 
To summarize, although new legislation determined the primary objective of monetary policy to be achieving the goal of price stability and granted the CBE legal instrument independence, the existence of the government's representatives in the MPC as voting members and the coercion of the $\mathrm{CBE}$ to extend finance to the government undermines factual independence of the $\mathrm{CBE}^{37}$. Moreover, although the comparison between Egypt and CPB came in favor of Egypt in some areas, the main shortcoming of macroeconomic policy in Egypt is the performance of the general budget including a high budget deficit and a significant contribution of the $\mathrm{CBE}$ in financing it.

\subsection{A commitment to price stability as a primary goal of monetary policy}

As mentioned, a commitment to price stability is based on two elements; (i) The CB should not target any other variable other than the rate of inflation and (ii) The CB should be transparent to the public regarding the exemptions of its target. We may explore the applicability of these two elements in case of Egypt as follows:

7.2.1 The CB should not target any other variable other than inflation rate: As mentioned, IT can be problematic if the $\mathrm{CB}$ has an implicit target for the FX rate. This point is supported by the experience of both Czech Republic and Brazil. When the CNB intervened in the FX market to fix the appreciation of domestic currency inflation targets were lost (Holub, 2004). In addition, despite adopting IT, the fears of a high pass-through effect led

\footnotetext{
${ }^{37}$ One of the tough critiques of the CCMP came from a Morgan Stanley report about the overriding of the government, specifically the prime minister, on both CCMP and the MPC of the CBE (Cevik, 2007).
} 
the BCB implicitly targeting the FX rate in an asymmetric way which in turn led the $\mathrm{BCB}$ to lose inflation targets.

By considering the experience of the CBE during the period of 19912003, Awad (2011) a thinks that the CBE adopted a dual-target policy (i.e. targeting the rate of growth of M2 and pegging the FX rate vis-à-vis the US dollar) because of the fears of a high pass-through effect ${ }^{38}$. Despite such a policy could bring the rate of inflation down during the nineties decade, the rate of inflation revived once more when the CBE was forced to devaluate domestic currency as of 2001 on the aftermath of economic shocks that occurred during the second half of the nineties decade. Al-Shawarby and Selim (2012) examine whether domestic inflation spikes in Egypt during the period 2001-2011were primarily caused by external food price shocks. One conclusion of this study is that domestic inflation in Egypt in the short run is caused by external shocks. The pass-through to domestic food inflation in the short run is high and reaches to $29 \%$ after six months and around two-thirds after a year.

However, Awad (2011) $)_{b}$ considered the impact of recent innovations in monetary policy on the monetary transmission mechanism in Egypt especially during the periods as of 2005 . One result of this study is that the CBE no longer intervene regularly in the FX market, and a sudden depreciation of domestic currency no longer significantly supports

\footnotetext{
${ }^{38}$ The pass-through effect in Egypt is thought to be high. Rabanal, Pau (2005) estimated the exchange rate pass-through effect in Egypt to both the wholesale price index (WPI) and CPI during the period of the exit from pegging to floating FX rate, i.e. the period of 2000-2004. While the pass-through effect was higher to the WPI (from 30\% to 60\%) and statistically significant, it was low and not statistically significant for the CPI. The weak relationship between exchange rate shocks and the changes in the CPI is explained by the relatively large share of goods with administrated prices included in the CPI series that was used until July 2003 (roughly one third to one half of the CPI items).
} 
domestic economic growth and its impact on domestic price level has relaxed.

\subsubsection{The CB should announce escape clauses for its inflation} targets: most inflation targeters construct what's called 'core inflation measure ${ }^{39}$. The logic behind the use of core inflation by CBs is explained by Bryan and Cecchetti (1994) as follows; the headline CPI inflation can incorporate a temporarily noise caused by sector-specific shocks, i.e. food and energy prices. Because these price changes do not constitute underlying monetary inflation, monetary authorities should avoid basing their decisions on them. One common solution to this problem is to measure the underlying or core component of inflation through excluding certain prices in the computation of the CPI based on the assumption that these are the ones with high variance noise component. Thus the existing $\mathrm{CPI}$ is reweighted by placing zero weights on the excluded components and the remaining weights are rescaled.

Like many other CBs, the CBE constructs its own core inflation measure through excluding the high volatile components from the headline CPI. The high volatile items that are excluded from the CPI include; (i) items with prices that are regulated by the government, which, according to the CBE estimates, represent $19.4 \%$ of the total CPI basket. (ii) Food items with prices that are inherently volatile since their supply largely depend on weather and harvest conditions, i.e. fruits and vegetables. They represent 8.8 percent of the CPI basket. Obviously, the core inflation measure used by the CBE removes the first round, or direct, effect of price movements in

\footnotetext{
${ }^{39}$ Literally, the term core inflation is used to indicate the long-run, or persistent, component of the measured price index, which is tied in some way to money growth.
} 
those items which are thought to be do not reflect the persistent, or underlying, monetary inflation pressures in the economy. According to the explanation by the $\mathrm{CBE}$, the second-round effects that these items' price movements have on the other components of the CPI basket are part of the underlying inflation pressures in the economy and hence they are fully reacted by the $\mathrm{CBE}^{40}$.

From the experience of $\mathrm{CPB}$, not all CBs announced escape clauses. While the BCB did not announce escape clauses, the CNB preferred to be more transparent to the public by explicitly announcing escape clauses whereas the NBP did not explicitly announce escape clauses but rather defined its stance in case of economic shocks have occurred.

Although the $\mathrm{BCB}$ did not announce escape clauses, it used a relatively wide range, 2-percentage point tolerance interval around the central target of inflation. In addition, the CNB did not announce escape clauses for its inflation targets in the early days of adopting IT because it was targeting the so-called net inflation during that time. The CNB announced escape clauses immediately after abstaining from targeting net inflation and announcing its intention to target headline CPI inflation in April 2001.

In the light of this, the CBE has many options to the escape clauses when it comes to the decision of implementing a full-fledged IT regime: (i) To target core inflation measure or to explicitly announce escape clauses, like the case of the Czech Republic. (ii) To determining the scale and duration of economic shocks that require an intervention by the $\mathrm{CB}$, like

\footnotetext{
${ }^{40} \mathrm{See} ;$ http://www.cbe.org.eg/Monetary-Policy/FrameWork.htm
} 
the case of Poland. (iii) To use a wide range for inflation targets without announcing escape clauses, like the case Brazil.

\subsection{Forecasting capabilities}

From the experience of $\mathrm{CPB}$, inflation targets were missed several times. Upon the explanation of the CNB, the non-fulfillment of inflation forecasts, resulting from both supply-side shocks and imperfections in the forecasting system is the main element behind undershooting inflation targets.

As mentioned, forecasting capabilities require three basic elements; (i) A model for inflation forecasting and inflation projections, (ii) The CB has to have clear idea about timing and the effect of monetary transmission mechanisms, and (iii) An inclusive and updated database on macroeconomic variables has to be in place.

Regarding the first and the second element, Egypt exhibits a better shape when the current state of knowledge that Egypt has is compared with its counterpart in the CPB in the start of their adoption of IT. So far, the main achievements that have been accomplished by the CBE are, ${ }^{41}$ (i) Moving from a quantitative operational target (excess reserves) to a price target (overnight inter-bank rate), and launching a corridor system in June 2005 to reduce volatility in the overnight inter-bank rate. (ii) Issuing CBE instruments in August 2005 as the primary instruments for liquidity management through open market operations. (iii) Enhancing the role of monetary policy operations to absorb or inject liquidity in the market through a publicly announced auction schedule. (iv) Using a small open

\footnotetext{
${ }^{41}$ See; http://www.cbe.org.eg/Monetary-Policy/FrameWork.htm
} 
economy gap model with forward looking expectations and endogenous monetary policy response. The model's equations have clear micro-based motivation, derived from first order principles of rational agents. (v) Constructing the core inflation measure. (vi) Al-Mashat (2008) reported that the CBE employed a VAR model to estimate; the pass-through from FX rate to CPI and WPI inflation rates, potential GDP, and monetary transmission mechanisms. In addition, the $\mathrm{CBE}$ is carrying out near-term inflation forecasts of inflation for one quarter ahead.

However, these achievements do have some imperfections; (i) The $\mathrm{CBE}$ does not publish either the model used for inflation forecasting, or even inflation forecasts. (ii) The CBE does not have a household survey of inflation expectations. (iii) The estimates of pass-through effect, potential GDP, and monetary transmission mechanisms published by the CBE's staff need to be updated. (iv) A research has to be implemented on the targeted rate of inflation that will not cause an eruption of public debt. (v) A dynamic stochastic general equilibrium model has to be built.

Regarding the third element, datasets are compiled in Egypt by different agencies, e.g. the central agency for public mobilization and statistics (CAPMAS), the ministry of planning (MOP), the CBE, and many other ministries, e.g. ministry of health and population, ministry of agriculture and land reclamation, etc. Because of limited coordination among these agencies and different standers, definitions, and methodologies used by them, inconsistencies and even contradictions appear in the Egyptian data. For example, different estimates of unemployment rate are produced by different agencies, e.g., MOP and CAPMAS. Also, vital statistics are collected by both CAPMAS and the 
ministry of health and population. In addition, produced data lack accuracy and do not fully satisfy users' needs concerning topics to be covered, frequency, format of data dissemination etc.

Using data quality assessment framework (DQAF), the IMF staff (2005) assessed the quality of data in Egypt. Their assessment included national accounts, price indices, government finance, money and balance of payment statistics. Despite several shortcomings in many areas, the most defects in the Egyptian data were found in the accuracy and reliability, the serviceability, and the accessibility of data. The defects in the accuracy and reliability of data were found in both national accounts and price indices prepared by the MOP and the CAPMAS successively. The defects in the serviceability of data are because of the dissemination of macroeconomic statistics does not fully meet the users' needs and there is no general oversight regarding the development and coordination of macroeconomic statistics. The defects in the accessibility of data include the difficulties in the availability of data equally and simultaneously among all interested parties.

In the light of this, Egypt has to improve and update its statistics to meet the international criteria, especially that used by the IMF under the DQAF.

\section{Conclusions}

Through exploring prerequisites of IT that have been accomplished and that which are still unfulfilled, this study intends to investigate challenges facing the $\mathrm{CBE}$ for adopting IT regime. The study exploits the experience of some emerging market economies (Czech Republic, Poland, 
and Brazil) in their early days of adopting IT to draw lessons that might be helpful for the case of Egypt. The study presumes that a country will apply IT once prerequisites of IT have been accomplished, given political intention to adopt IT. The main conclusions of the study came as follows:

(i) Two motivations were behind the adoption of IT in many countries, namely, IT is regarded as a way of reforming monetary policy via anchoring individuals' expectations of inflation around an announced inflation target, and IT does not worsen economic performance.

(ii) Three prerequisites are frequently demanded for a successful IT; factual independence of the $\mathrm{CB}$, a commitment to price stability as a primary goal of monetary policy, and forecasting capabilities have to be in place.

(iii) IT is a problematic in the cases of Low credibility of CB, Fragile fiscal policy, FX intervention by $\mathrm{CB}$, and asset-price bubbles.

(iv) Many lessons are extracted from the experience of CPB. Among these lessons; Firstly, The real intention to achieve price stability on the aftermath of economic crises and price skyrocketing followed it led CPB to swiftly implement IT. Secondly, despite factual independence of CBs in $\mathrm{CPB}$, inflation targets were missed several times generally because of FX interventions induced by fears of high pass-through effect and forecasts' flows resulted from lacking forecasting capabilities.

(v) By comparing the current position of Egypt to that of CPB the study concludes that; Firstly, unlike to CPB the CBE is not factually independent because of the existence of the government's representatives in the MPC as voting members and the coercion of the CBE to extend 
finance to the government. Moreover, high budget deficit and the significant contribution of the $\mathrm{CBE}$ in financing it represent the main shortcoming of macroeconomic policy in Egypt compared with CPB. Secondly, since there are other options to escape clauses of the inflation target, announcing escape clauses is not binding to the CBE. Thirdly, the $\mathrm{CBE}$ is reticent and does not disclose enough information about its forecasting capabilities. Fourthly, the Egyptian data incorporate many defects include the accuracy and reliability, the serviceability, and the accessibility of data.

In the light of this, challenges facing the CBE for adopting IT regime can be summarized as follows:

(i) The CBE should play a more active role to convince decisionmaking circuits inside the government for the adoption of IT as a way of both reforming monetary policy and achieving the goal of price stability.

(ii) The CBE should be factually independent. Since factual independence of CBs is indispensible task for a successful application of IT, the MPC of the CBE should not incorporate government's representatives as voting members and the $\mathrm{CBE}$ should not be obliged to finance budget deficit ${ }^{42}$.

(iii) Coordination between monetary policy and fiscal policy should be established. Since determining the inflation target that has to be hit by the

\footnotetext{
43 The existence of fiscal dominance makes it risky for any country to adopt IT. Consequently, financing the budget deficit by the CBE should be prohibited. In addition, the government should finance its operations in the economy using real resources without crowding the private sector in the credit market. Accordingly, the general budget of the state and perhaps both the role and size of the governmental sector in the economy have to be restructured to comply with the main function of the CBE.
} 
$\mathrm{CBE}$ in the medium to long-term is the responsibility of the CCMP, the inflation target should be determined upon projections of the long run price level, which ensure the government's solvency, i.e. the rate of inflation that will not cause an eruption of public debt. In this regard, intensive research studies are needed to tackle this issue.

(iv) Extensive studies under different small-scale models have to be implemented to ensure a satisfactory understanding of the following issues; the degree of the exchange rate pass-through effect, the level of real exchange rate, both timing and effect of monetary transmission mechanisms. In addition, large-scale macroeconomic models are needed for the purpose of inflation projections under different scenarios of economic conditions.

(v) Several questions are still unfulfilled and need to be investigated openly by both academic researchers and the CBE's staff; Which measurement of price level that will be targeted?, i.e. CPI inflation or core inflation measure? What are variables that will be included in the objective function of the CBE? And what are relative weights that will be assigned to these variables? What is the model that fits the Egyptian economy? How would the CBE react to both supply shocks and asset-price bubbles? What is the equilibrium level of both real FX rate and property prices? How can the CBE detect deviations of both the actual real FX rate and actual property prices from their equilibrium levels in real time? Are the MPC members qualified enough to give adequate assessment of the risks of the forecasts and the associated decisions?

(vi) Some institutional arrangements are urgently needed both to implement a household survey of inflation expectations and to improve and 
update the Egyptian statistics in order to meet the international criteria, especially that used by the IMF under the DQAF. 


\section{References}

Al-Mashat, Rania (2008). 'Monetary Policy in Egypt: A Retrospective and Preparedness of Inflation Targeting', ECES, Working Paper No. 134. [Online] Available at:

http://www.eces.org.eg/Publications/View_Pub.asp?p_id=10\&p _detail_id=18\#mytop

Al-Shawarby, Sherine and Selim, Hoda (2012). ' Are International Food Price Spikes the Source of Inflation in Egypt?', The World Bank, Policy Research Working Paper No. 6177.

Arestis, philip, Fernando de Paula, Luiz \& Ferrari-Filho, Fernando (2008). 'Inflation Targeting in Brazil. The Levy Economics Institute of Bard College', WP No. 544. [Online] Available at: http://www.levy.org/pubs/wp_544.pdf

Awad, Ibrahim L. (2008). 'Towards Measurement of Political Pressure on Central Banks: The case of the Central Bank of Egypt', Prague Economic Papers, Vol. XVII, No 3, PP. 254-275.

Awad, Ibrahim L. (2011)a. 'Assessing the Performance of Monetary Policy under Economic Reform and Structural Adjustment Program: The Case of Egypt', Review of Economic and Business Studies, Vol. 4 (1), PP 201-224.

Awad, Ibrahim L. (2011)b. 'The Impact of Recent Innovations in Monetary Policy on the Monetary Transmission Mechanism in Egypt', Economic Studies, Vol. XX (4), PP.186-209.

Ball, L. (1999).' Policy Rules for Open Economies', In; Taylor, J. B. (ed.), Monetary Policy Rules, University of Chicago Press, PP. 127144.

Ball, Laurence and Niamh Sheridan (2003). ' Does Inflation Targeting Matter?', IMF Working Paper No 03/129.

Barbosa-Filho, Nelson H. (2007). 'Inflation Targeting in Brazil: 19992006'. [Online] available at:

http://www.networkideas.org/feathm/oct2007/pdf/Barbosa.pdf

Batini, N. and Nelson, E. (2000). 'Optimal Horizons for Inflation Targeting', Bank of England.

Batini, N., and Haldane, A. G. (1999). ' Forward-looking rules for monetary policy', In; Taylor, J. B. (ed.), Monetary Policy Rules, University of Chicago Press, PP. 157-192. 
Batini, N., Breuer, P., Kochhar, K., and Roger, S. (2006). 'IMF:

Inflation Targeting and the IMF'. [Online] Available at: http://www.imf.org/external/np/pp/eng/2006/031606.pdf

Batini, N., Kuttner, K., and Laxton, D. (2005). World Economic

Outlook: Building Institutions, Ch. IV. IMF, September, 2005.

[Online] Available at:

http://www.imf.org/external/pubs/ft/weo/2005/02/index.htm

Benigno, P., and Woodford, M.(2006). 'Optimal Inflation Targeting Under Alternative Fiscal Regimes', Working Paper, No. 407.

Bernanke, Ben S. \& Woodford, Michael (eds.) (2005). The InflationTargeting Debate, Chicago and London: The University of Chicago Press.

Bernanke, Ben S., and Mishkin, Fredirec S. (1997). 'Inflation Targeting: A New Framework for Monetary Policy?', Journal of Economic Perspective, Vol. II, No.2, PP.97-116.

Bernanke, Ben S., laubach, Thomas, Mishkin, Frederic S. \& Posen, Adam S. (1999). Inflation Targeting: Lessons from the International Experience, Princeton, New Jersey: Princeton University Press.

Bharucha, N. and Kint, C. (1998). ' Inflation Targeting in A small Open Economy', Reserve Bank of Australia, Research Discussion Paper No. 9807.

Blanchard, O. (2004). 'Fiscal Dominance and Inflation Targeting: lessons from Brazil', MIT Working Paper.

Blanchard, O. J. and Fisher, S. (1993). Lectures on Macroeconomics, Massachusetts: MIT Press.

Blinder, A. S. (2006). ' Monetary Policy Today: Sixteen Questions and about Twelve Answers', in; Banco de Espana Conference on Central Banks in the 21st Century, Madrid, June 8-9, 2006.

Blinder, Alen, S. and Reis, Ricardo (2005). 'Understanding the Greenspan Standard', In; Federal Reserve Bank of Kynsas City Symposium, The Greenspan Era: Lessons for the Future, Jackson Hole, Wyoming, August 25-27, 2005.

Bogdanski, Joel, Antonio Tombini, Alexandre \& Ribeiro da Costa Werlang, Sérgio (2000). 'Implementing Inflation Targeting in Brazil', Working Papers Series. [Online] Available at: http://www.cemla.org/pdf/v_red_bogdansky.PDF 
Bryan, Michael F., and Cecchetti, Stephen G. (1994). ' Measuring Core Inflation, In; Monetary Policy, N. Gregory Mankiw (ed.), The University of Chicago Press, PP. 195-219.

Budnik, Katarzyna, et al. (2008). 'NECMOD', National Bank of Poland (NBP). [Online] Available at:

http://www.informest.it/docs/documenti/PL_20081001165552_n ecmod_description2008.pdf

Carare, Alena, Schaechter, Andrea, Stone, Mark \& Zelmer, Mark (2002). 'Establishing Initial Conditions in Support of Inflation Targeting', IMF Working Paper, WP/02/102. [Online] Available at: http://www.imf.org/external/pubs/ft/wp/2002/wp02102.pdf

Carlin, W. and Soskice, D. (1990). Macroeconomics and the Wage Bargain, New York: Oxford university Press.

CBE (2005). Monetary Policy Statement, June 2, 2005 (English). [Online] Available at: http://www.cbe.org.eg/

CBE (2006-2007). Economic Review, Vol. 47, No. 2. [Online] Available at: http://www.cbe.org.eg/Publications.htm

CBE, Annual report 2010/2011. [Online] Available at: http://www.cbe.org.eg/Publications.htm

Cecchetti, Stephen G. (2005). 'The Brave New World of Central Banking: The Policy Challenges Posed by Asset Price Booms and Busts', CNB, Working Paper No 14.

Cecchetti, Stephen G., and Ehrmann, Michael (1999). 'Does Inflation Targeting Increase Output Volatility?: An International Comparison of Policymakers' Performances and Outcomes, NBER Working Paper series, Working Paper, No.7426.

Cevik, Serhan (2007). 'When a prime minister makes monetary policy', Morgan Stanley report about Egypt. Available at; http://www.morganstanley.com/views/gef/archive/2007/200703 28-Wed.html

Clarida, Richard, Gali, Jordi, and Gertler, Mark (1999). 'The science of Monetary policy: A New Keynessian Perspective', Journal of Economic Literature, 37, pp 1661-1707.

CNB (2008). Ten Years of Inflation Targeting 1998-2007. [Online] Available at: http://www.cnb.cz/m2export/sites/www.cnb.cz/en/public/publica tions/download/10_years_inflation_targeting_en.pdf 
Debelle, Guy, Masson, Paul, Savastano, Miguel \& Sharma, Sunil (1998). Inflation Targeting as a Framework for Monetary Policy. Washington, DC: IMF.

Disyatat, Piti and Galati, Gabriele (2005). 'The effectiveness of foreign exchange intervention in emerging market countries: evidence from the Czech korunas', Bank for International Settlements, BIS Working Papers, No 172.

Eichengreen, Barry, Masson, Paul, Savastano, Miguel \& Sharma, Sunil (1999). 'Transition Strategies and Nominal Anchors on the Road to Greater Exchange-Rate Flexibility', Essays in International Finance, No 213. [Online] Available at: http://www.princeton.edu/ ies/IES_Essays/E213.pdf

Epstein, Gerald (2007). 'Central banks, inflation targeting and employment creation', Economic and Labor Market Papers, ILO.

European Central Bank (1999), Monthly Bulletin, January.

Fanizza, Domenico, and Sderling, Ludving (2006). 'Fiscal determinants of Inflation: A Primer for the Middle East and North Africa', IMF Working Paper.

Fraga, Arminio (2000). 'Monetary Policy during the Transition to a Floating Exchange Rate: Brazil's Recent Experience', Finance \& Development, March, 37(1). [Online] Available at: http://www.imf.org/external/pubs/ft/fandd/2000/03/fraga.htm

Fraga, Arminio, Goldfajn, Ilan \& Minella, Andre (2003). 'Inflation targeting in Emerging Market Economies', NBER Working Paper No. 10019. [Online] Available at: http://www.nber.org/papers/w10019

Holub, Tomas (2004). 'Foreign Exchange Intervention Under Inflation Targeting: The Czech Experience', $C N B$, Internal Research and Policy Note.

Hu, Yifan (2003). 'Empirical Investigations of Inflation Targeting', WP/03/6. [Online] Available at: http://www.iie.com/publications/wp/03-6.pdf

IMF (2005). 'Arab Republic of Egypt: Report on the Observance of Standards and Codes-Data Module', IMF Country Report No. 05/238, Washington, DC: IMF.

IMF (2007). 'Arab Republic of Egypt: Selected Issues', IMF country report No. 07/381, December 2007, Washington, DC: IMF. 
Issing, Otmar (2009). 'Asset Prices and Monetary Policy', Cato Journal, Vol. 29, No. 1, PP. 45-51.

Jonas, Jiri and Mishkin, Frederic S. (2003). 'Inflation Targeting in Transition Countries: Experience and Prospects', NBER Working Paper Series, Working Paper 9667. [Online] Available at: http://www.nber.org/papers/w9667

Kamar, Bassem \& Bakardzhieva, Damyana (2003). 'Economic Trilemma and Exchange Rate Management in Egypt', Review of Middle East Economics and Finance, Vol. 3(2). [Online] Available at: http://www.bepress.com/rmeef/vol3/iss2/art1/

Khan, Mohsin S. (2003). 'Current Issues in the Design and Conduct of Monetary Policy', IMF Working Paper, WP/03/56. [Online] Available at: SSRN: http://ssrn.com/abstract=879131

King, Mervyn (2005). 'What Has Inflation Targeting Achieved?', In; The Inflation Targeting Debate, Ben S. Bernanke and Michael Woodford. Chicago and London(eds): The University of Chicago Press.

Kohn, Donald L. (2009). ' Monetary Policy and Asset prices Revisited', Cato Journal, Vol. 29, No. 1, PP. 31-44.

Korenok, O., and Radchenko, S. (2006). 'Expectations Anchoring in Inflation Targeting Regimes', Working Paper.

Landerretche, Oscar, Vittorio Corbo and Klaus Schmidt-Hebbel (2001). 'Does Inflation Targeting Make a Difference?', Central Bank of Chile, Working Paper No 106.

Loyo, Eduardo (1999). 'Tight Money Paradox on the Loose: A Fiscalist Hyperinflation', John Kennedy School of Government, Harvard University. Available at; http://sims.princeton.edu/yftp/Loyo/LoyoTightLoose.pdf

MacCallum, B. T. and Nelson, E. (1999). 'Nominal Income Targeting as Open-Economy Optimizing Model', Journal of Monetary Economics, Vol. 43 (3) PP. 553-578.

Masson, Paul R., Savastano, Miguel A. \& Sunil Sharma (1998). 'Can Inflation Targeting be a Framework for Monetary Policy in Developing Countries?', Finance \& Development. [Online] Available at:

http://www.imf.org/external/pubs/ft/fandd/1998/03/pdf/masson.p $\underline{\mathrm{df}}$ 
Mishkin, Frederic S. (1999). 'International Experiences with Different Monetary policy Regimes', NBER, Working Paper No 7044.

Mishkin, Frederic S. (2000). 'Inflation Targeting in Emerging Market Countries', NBER Working Paper 7618. [Online] Available at: http://www.nber.org/papers/w7618

Mishkin, Frederic S. (2007). 'Housing and the Monetary Policy

Transmission Mechanism', NBER Working Paper Series,

Working Paper 13518. Available at:

http://www.nber.org/papers/w13518.

Mishkin, Fredric S. \& Schmidt-Hebbel, Klaus (2001). 'One Decade of Inflation Targeting in the World: What Do We Know and What Do We Need to Know?', NBER Working Paper No 8397. [Online] Available at: http://www.nber.org/papers/w8397

Mishkin, Fredric S. (2004). The Economics of Money, Banking, and Financial Markets (seventh edition), Pearson International Edition: Pearson Addition Wesley.

Neumann, Manfred J.M. and Jürgen von Hagen (2002). 'Does Inflation Targeting Matter?', The Federal Reserve Bank of St. Lous. [Online] Available at:

http://research.stlouisfed.org/publications/review/02/07/127148Neuman.pdf

Oxford Analytica (2005). 'Egypt: Monetary Transparency', Country Report, November 2005. [Online] Available at: http://www.calpers.ca.gov/eipdocs/investments/assets/equities/in ternational/permissible/egypt-monetary-report.pdf

Rabanal, Pau (2005). 'Arab Republic of Egypt: Selected Issues', IMF country report No. 05/179, June 2005, Washington, DC: IMF

Roger, Scott (2009). ' Inflation Targeting at 20: Achievements and Challenges', IMF Working Paper No. 236

Rotemberg, J. and Michael Woodford (1999). ' Interest Rate Rules in an Estimated Sticky Price Model', in Monetary Policy Rules, John B. Taylor (ed.)

Rudebusch, G. and Svensson, L.E.O. (1999). 'Policy Rules for Inflation Targeting' In; Monetary Policy Rules, Taylor, John B. (ed.), University of Chicago Press, PP. 203-262.

Schaechter, Andrea, Stone, Mark R. \& Zelmer, Mark (2000). 'Adopting Inflation Targeting: Practical Issues for Emerging Market Countries', Occasional Paper 202, Washington DC: IMF. 
Schmidt-Hebbel, Klaus \& Tapia, Matias (2002). 'Monetary Policy Implementation and Results in Twenty Inflation-Targeting Countries', Central Bank of Chile, Working Papers No 166. [Online] Available at: http://www.bcentral.cl/ estudios/ documentos-trabajo/pdf/dtbc166.pdf

Sims, Christopher A. (2005). 'Limits to Inflation Targeting', In: The Inflation-Targeting Debate, Ben S. Bernanke and Michael Woodford (eds.), Chicago and London: The University of Chicago Press.

Svensson, L. E. O. \& Woodford, M. (2005). 'Implementing Optimal Policy Through Inflation-Forecast Targeting', In; The Inflation Targeting Debate, Bernanke, Ben S., and Woodford, M. (eds.), Chicago University Press. PP 19-83.

Svensson, L. E. O. (1995). 'Optimal Inflation Targets, Conservative Central Banks, and Linear Inflation Contracts', NBER Working Paper, No.5251.

Svensson, L. E. O. (1997), 'Inflation Targeting: some extensions' mimeo, IIES, Stockholm University.

Svensson, L. E. O. (1998). 'Open-economy Inflation Targeting', NBER working Paper series, WP 6545.

Svensson, L. E.O. (1998). 'Inflation Targeting as a Monetary Policy Rule', Seminar Paper, No.646.

Truman, Edwin. M. (2003). Inflation Targeting in the World Economy, Washington, DC: Institute for International Economics.

Walsh, Carl E. (2009). 'Using Monetary Policy to Stabilize Economic Activity', In; Jackson Hole Symposium on Financial Stability and Macroeconomic Policy, August 20-22, 2009.

Williamson, John \& Mahar, Molly (1998). 'A Survey of Financial Liberalization', Essays in International Finance, No. 211. [Online] Available at: http://www.princeton.edu/ ies/IES_Essays/E211.pdf

Woodford, M. (2003). Money, Interest, and Prices. Princeton; Princeton University Press.

Woodford, Michael (1998). 'Optimal Monetary Policy Inertia', mimeo, Princeton University 